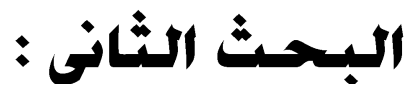

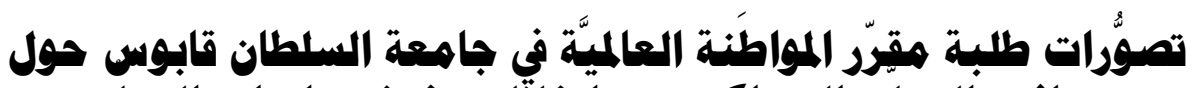

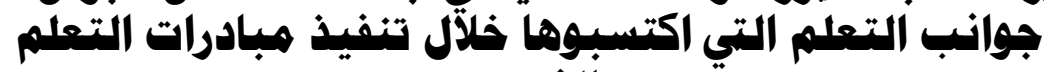
الفدهي

\author{
: \\ د. سيف بن ناصر المعمري \\ أستاذ مشارك بكليت التربيت جامعتر السلطيان قابوس \\ مسقط سلطنت عمان
}





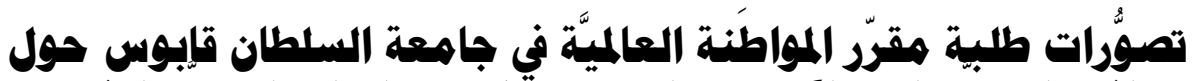

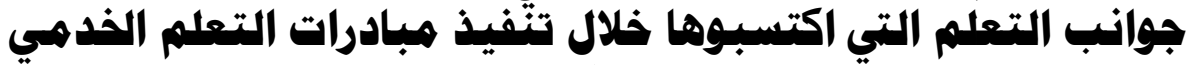

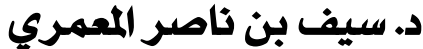

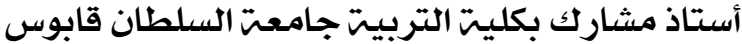

مسقط سلطنت عمان

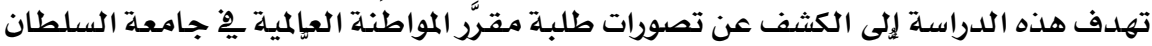

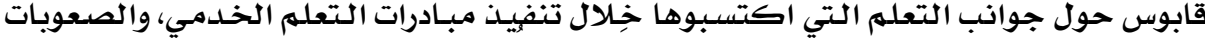

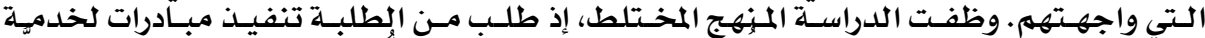

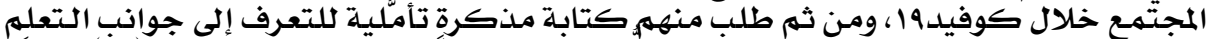

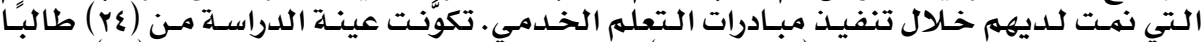

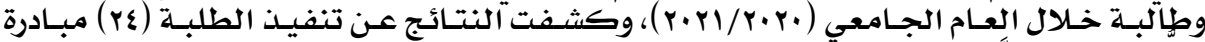

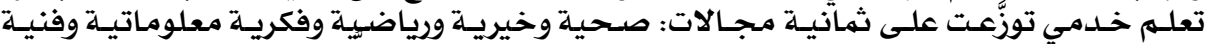

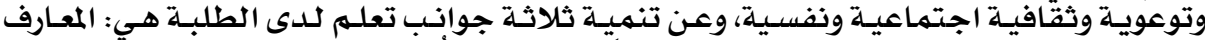

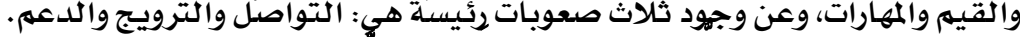

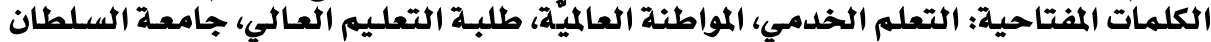
قابوس.

Perceptions of students of global citizenship course at Sultan Qaboos University about the aspects of learning that they acquired during the implementation

Dr. Saif bin Nasser Al-Maamari

of service-based learning initiatives

Abstract

This study aims to reveal the perceptions of students of the global citizenship course at Sultan Qaboos University about the aspects of learning that they acquired during the implementation of service-learning initiatives, and the difficulties they encountered. The study employed the mixed approach, where students were asked to implement community service initiatives during Covid 19, and then they were asked to write a reflective paper to identify the aspects of learning that they developed during the implementation of servicelearning initiatives. The study sample consisted of (24) male and female students during the academic year (2020/2021). The results revealed that the students implemented (24) service-learning initiatives that were distributed over eight areas: health, charitable, sports, intellectual, informational, artistic, awareness, cultural, social and psychological. In addition, these initiatives help students to develop three aspects of learning: knowledge, values, and skills. The analysis showed that students encountered a set of difficulties during their implementation of service-learning initiatives which were classified into three categories: communication, promotion and support. Keywords: Service learning, global citizenship, higher education students, Sultan Qaboos University.

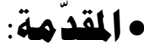

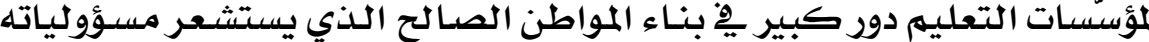

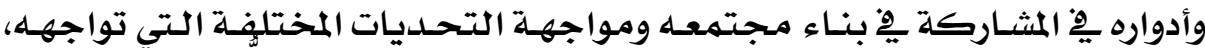

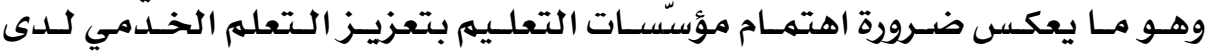




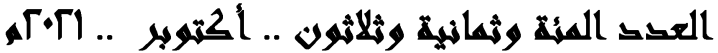

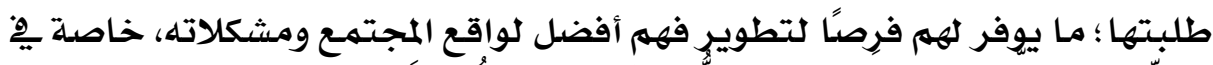

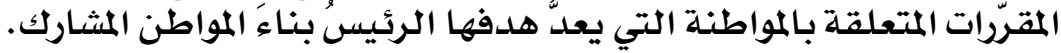

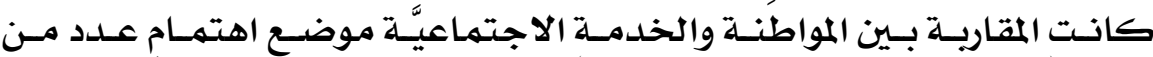

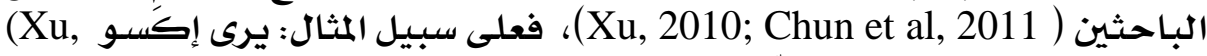

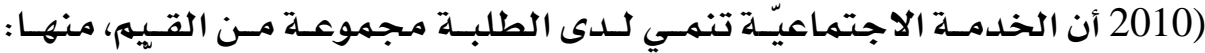

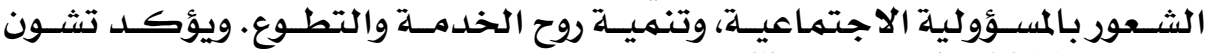

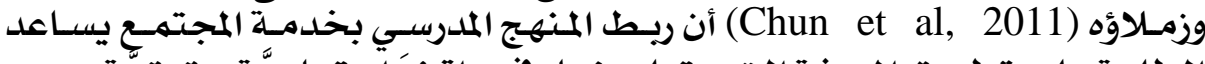

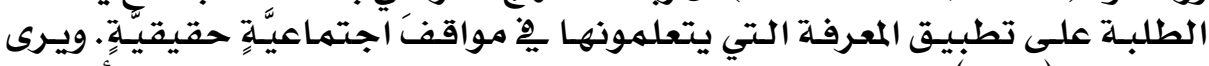

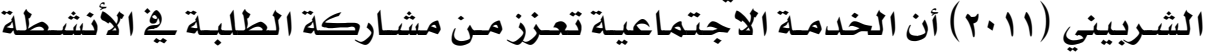

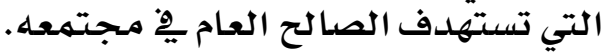

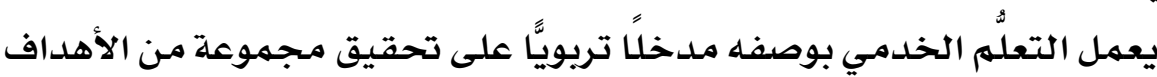

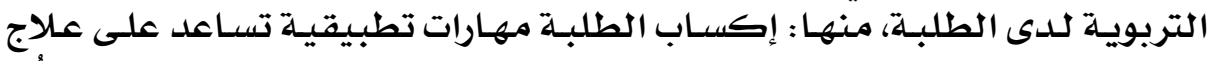

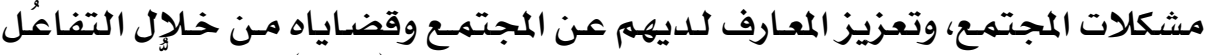

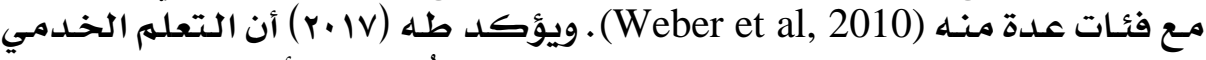

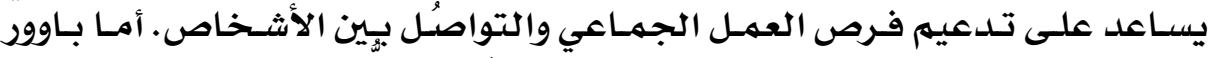

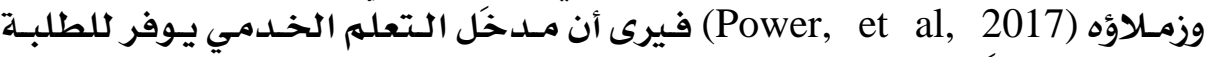

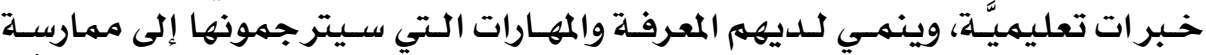

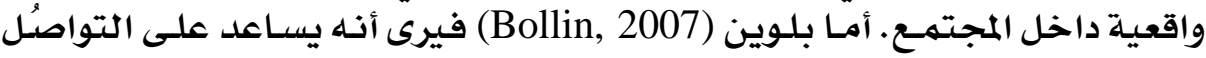

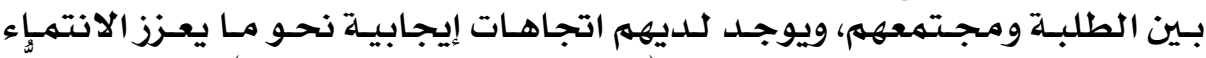

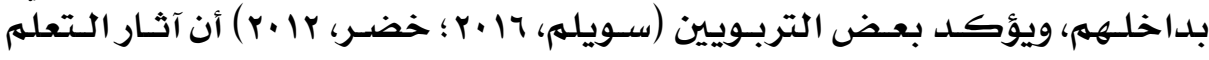

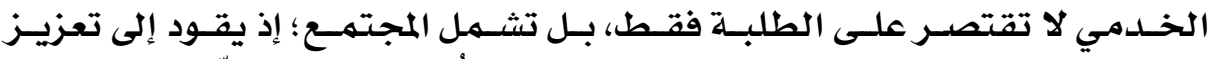

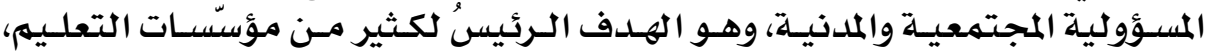

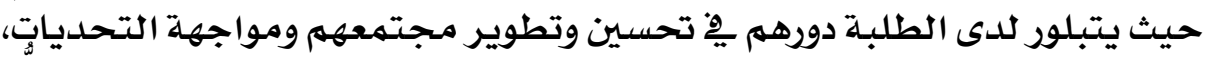

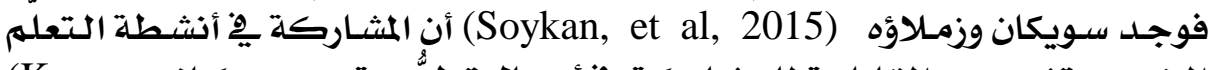

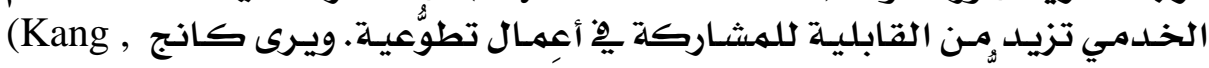

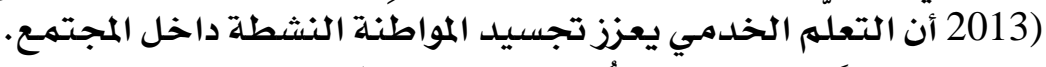

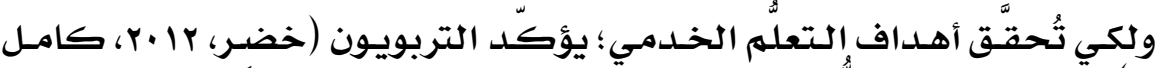

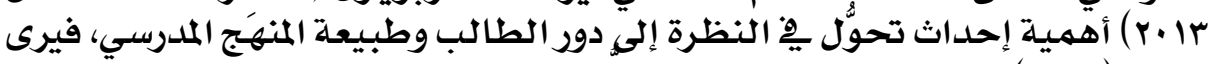

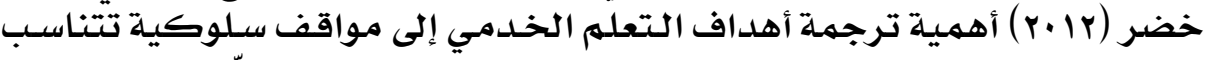

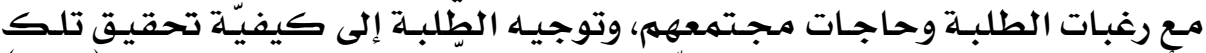

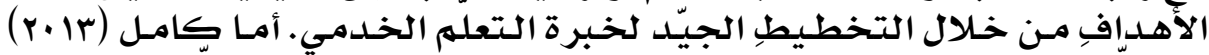

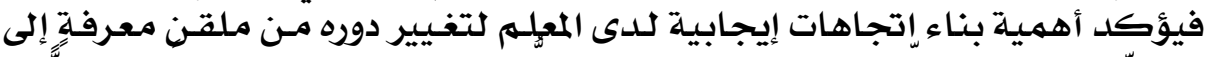

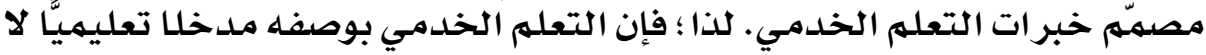

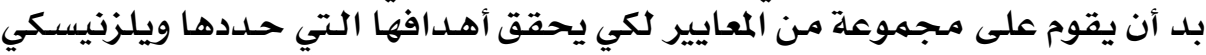
وكومي (Wilczenski \& Coomey, 2008)، ومنهو معنها المعايير الآتية:

\section{$\varepsilon Y$}




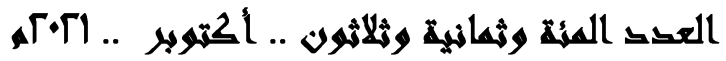

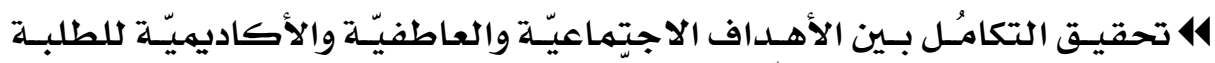

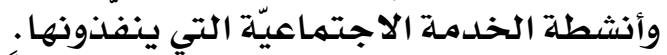

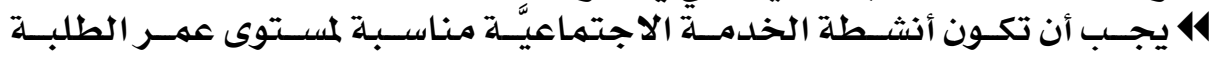

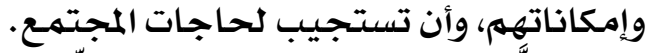

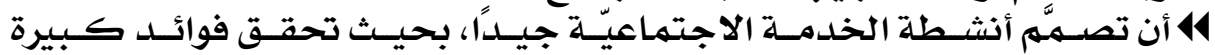
للطلبـة.

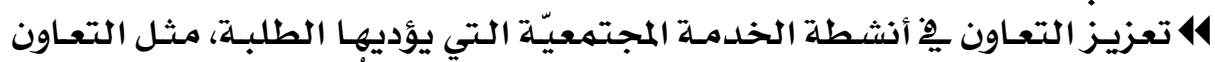

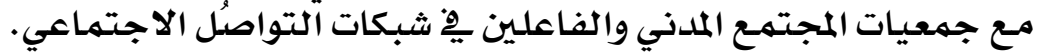

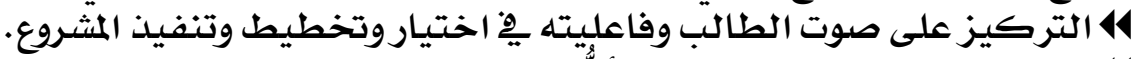

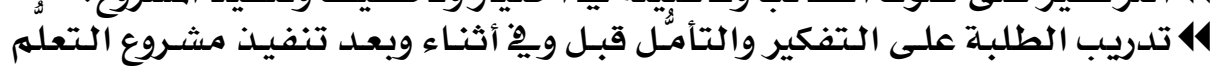
الخدهي.

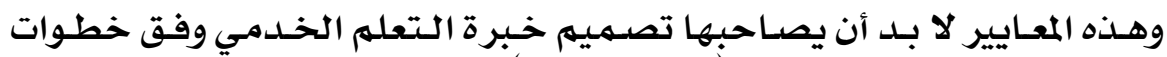

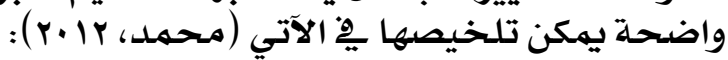

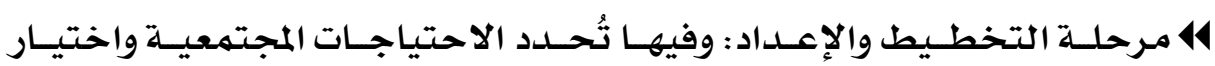

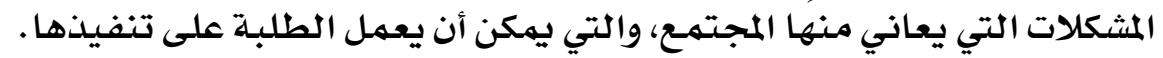

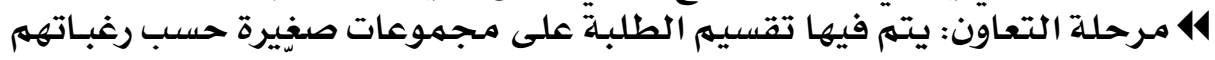

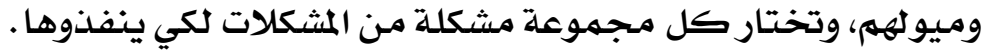

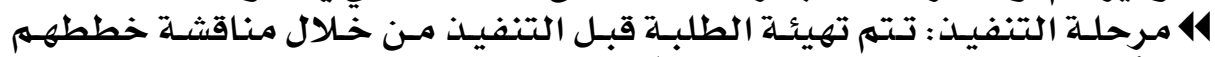

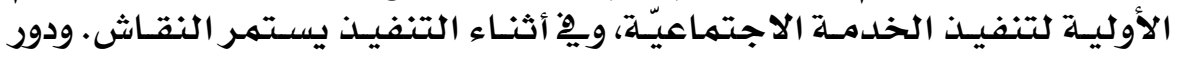

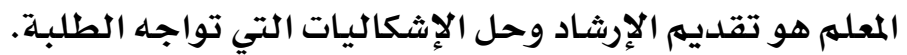

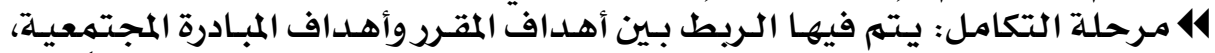

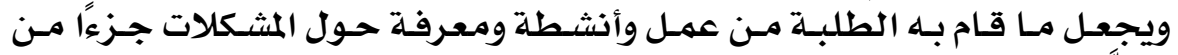

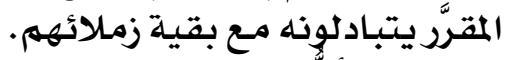

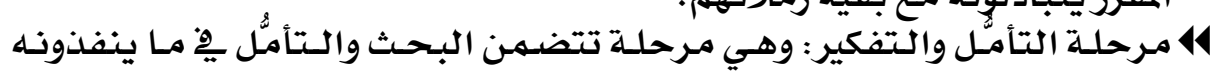

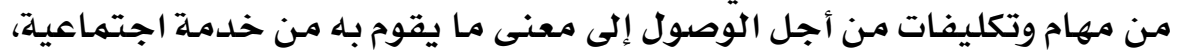

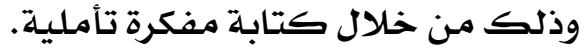

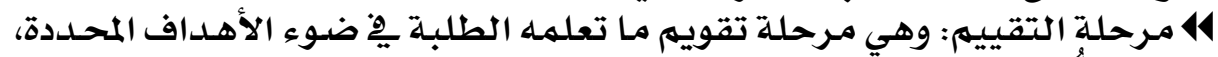

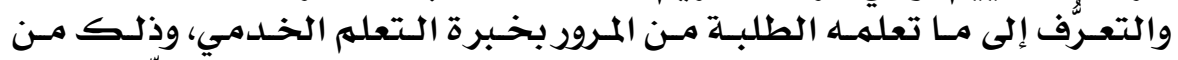

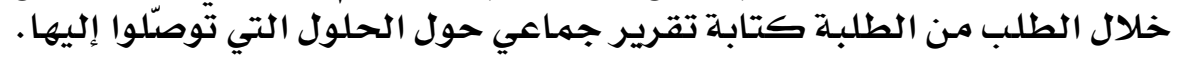

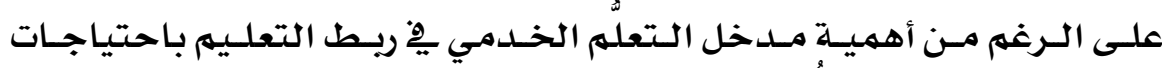

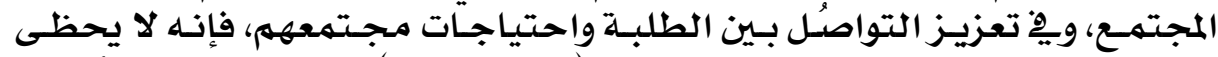

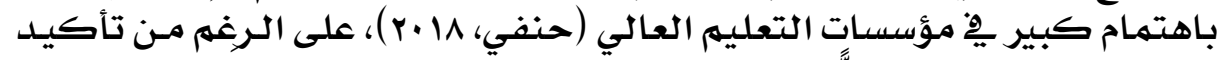

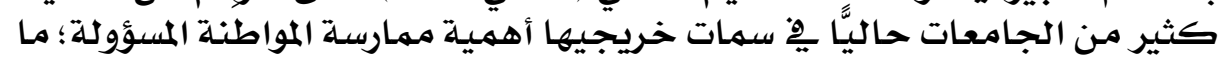

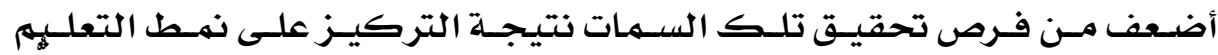

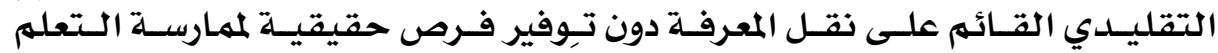

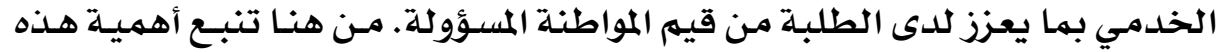

\section{$\varepsilon \boldsymbol{y}^{\mathbf{n}}$}




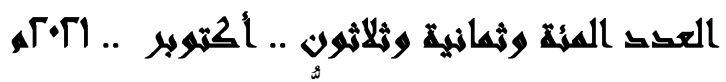

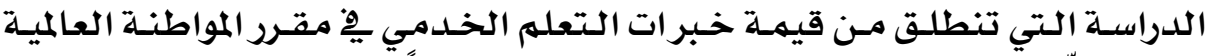

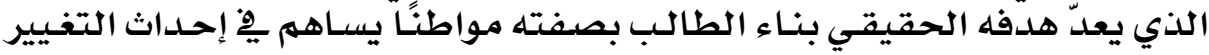

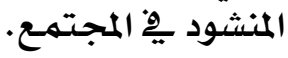

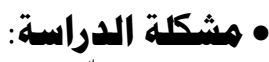

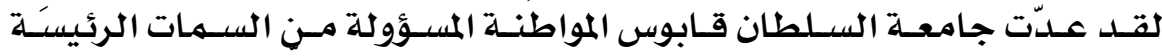

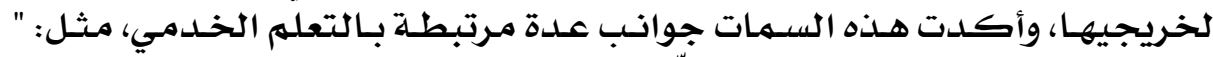

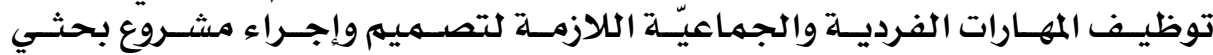

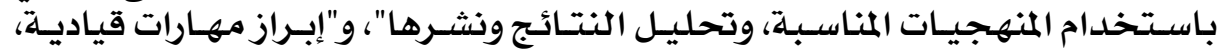

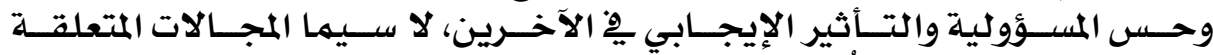

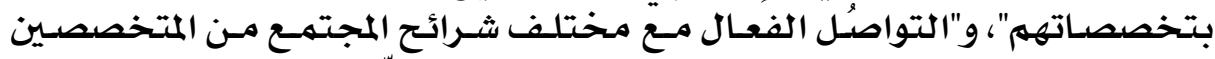

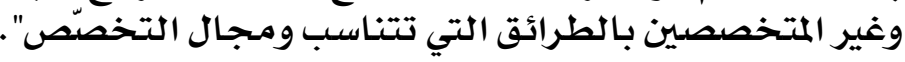

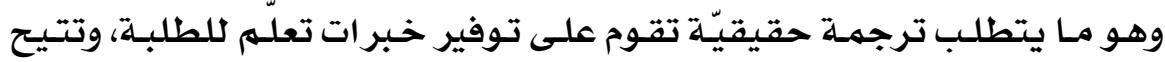

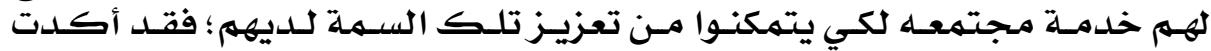

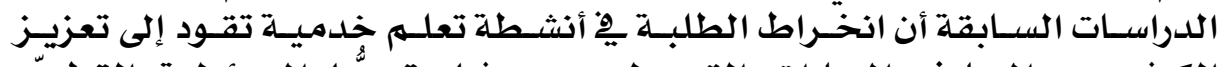

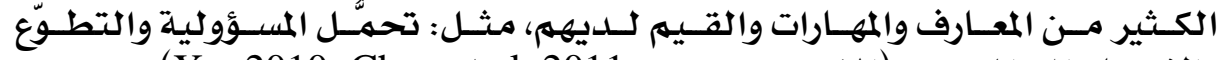

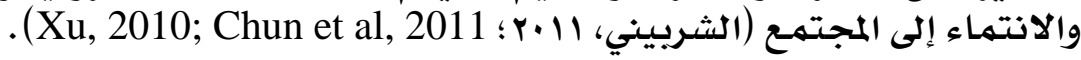

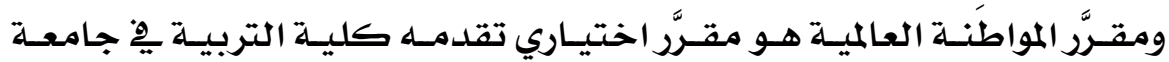

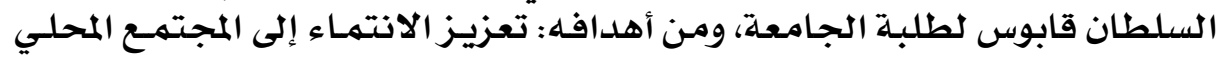

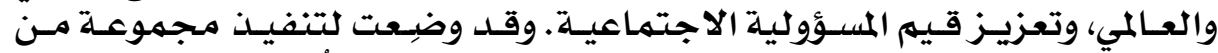

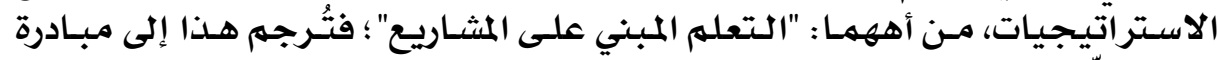

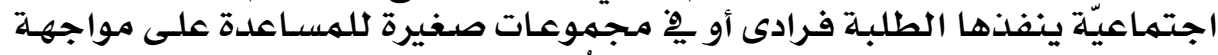

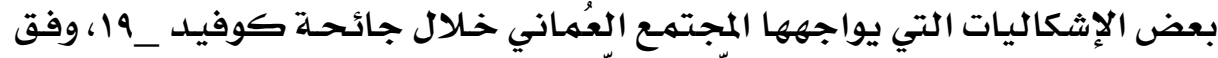

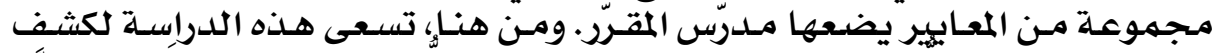

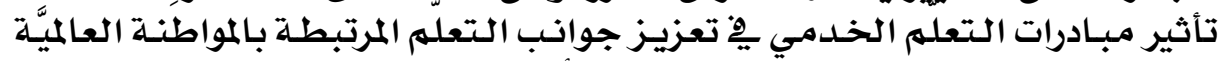
لدى الطلبة. وتتلخص مشكلة الدراسة يِّ الأسئلة الآتية:

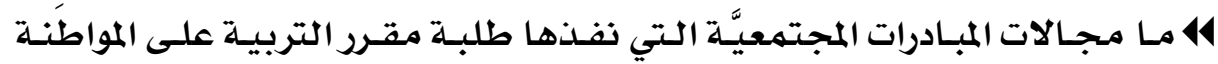

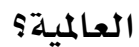

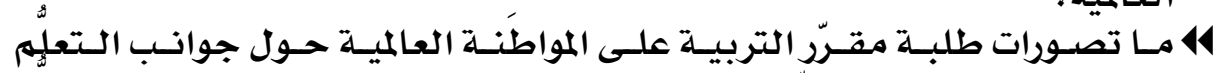

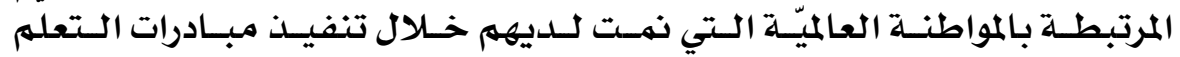

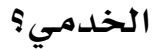

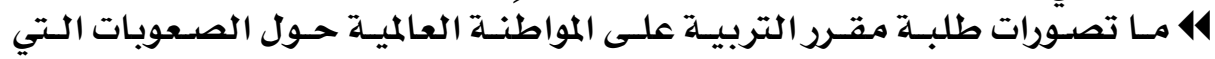
واجهتهم خلال تنفيذ مبادرات التعلم الخدمي.

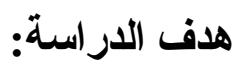

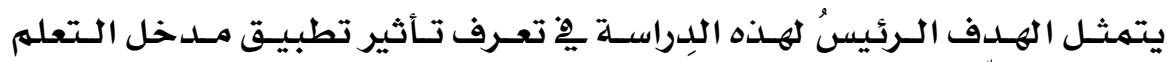

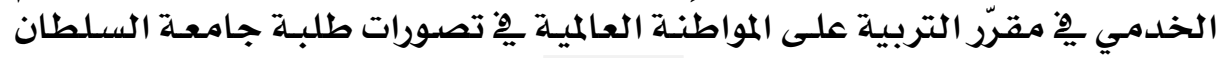

\section{$\varepsilon \varepsilon$}




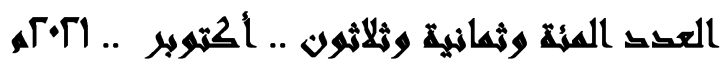

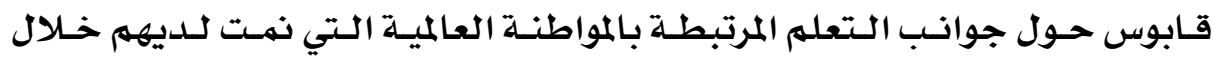

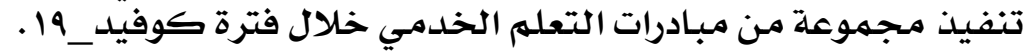

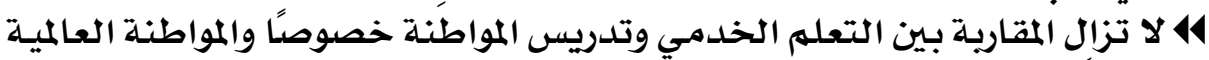

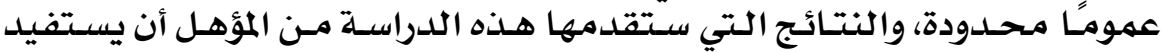

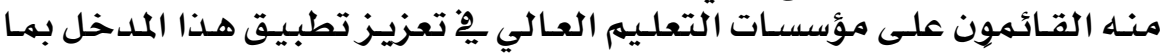

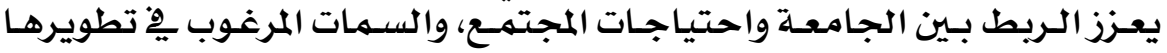
لدى الطلبـة.

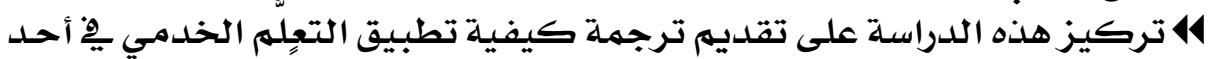

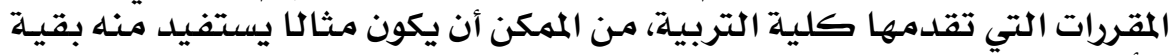

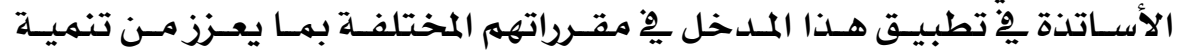

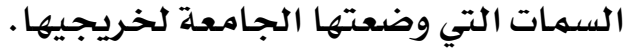

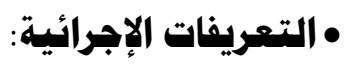

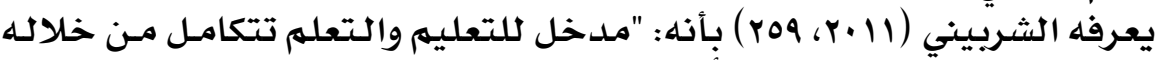

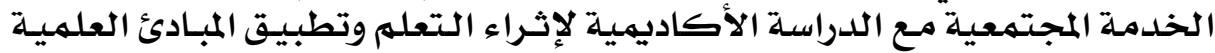

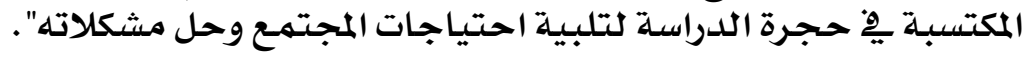

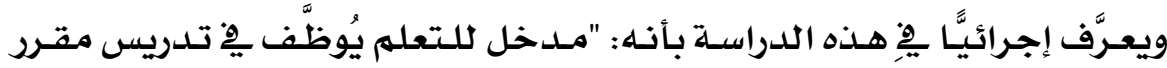

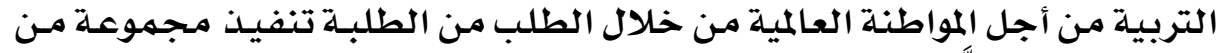

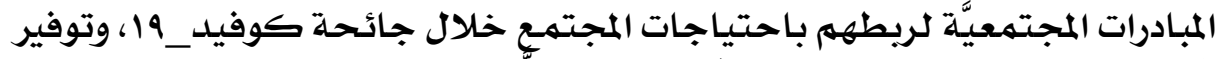

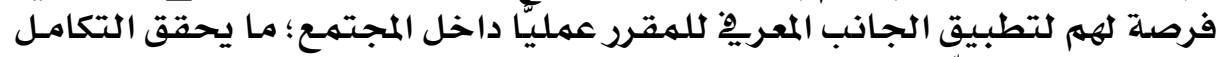

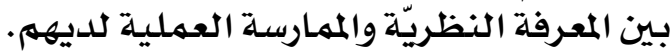

• تصورات الطالبة:

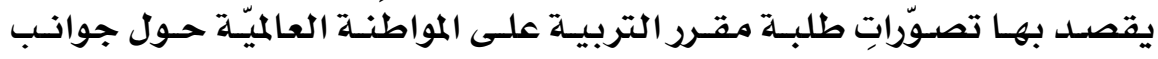

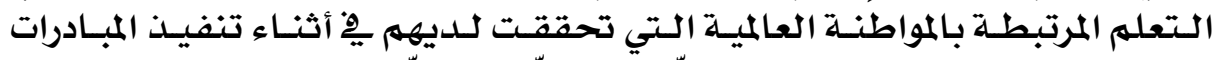

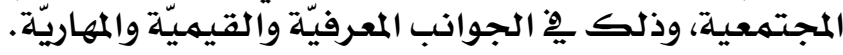
• طلبة هقرر تربية المواطنة العلاليَّة:

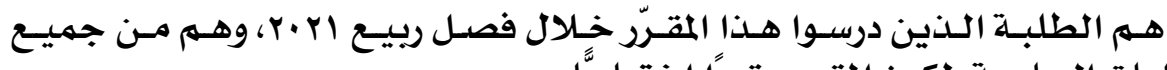

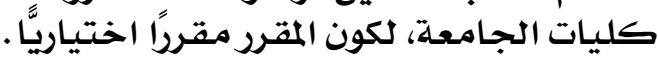

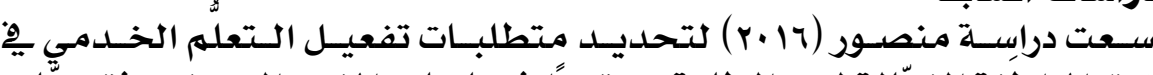

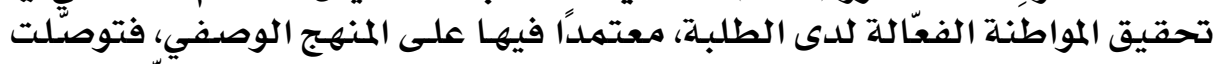

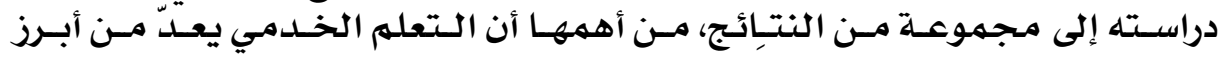

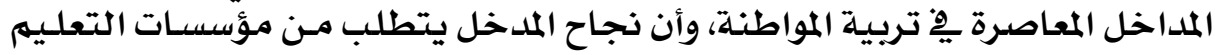
نشر ثقافة تطبيقه بين أسـاتذتها.

\section{\&O}




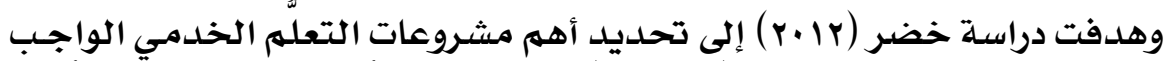

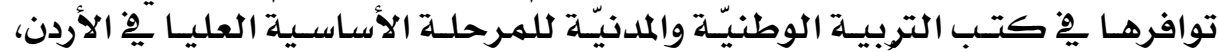

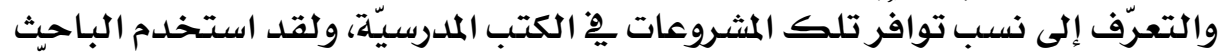

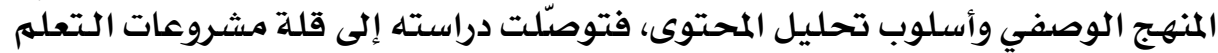

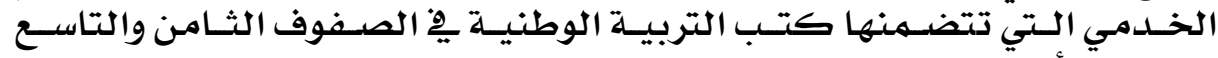
والعاشر الأساسية.

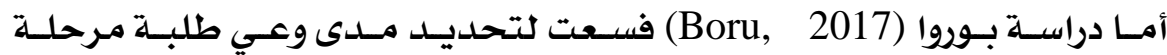

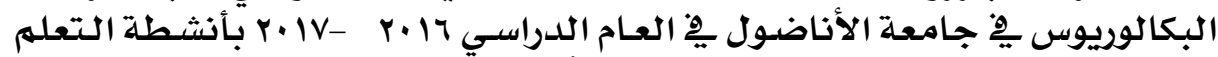

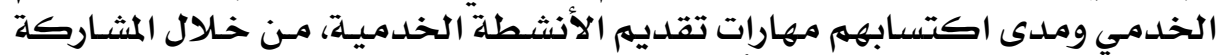

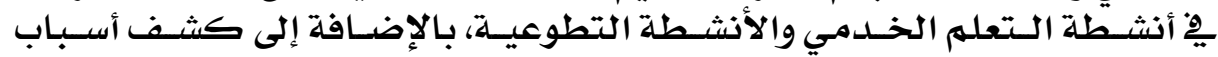

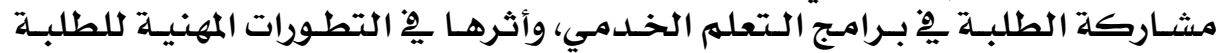

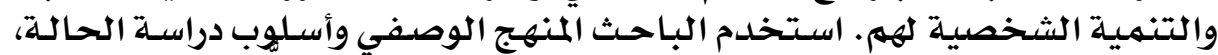

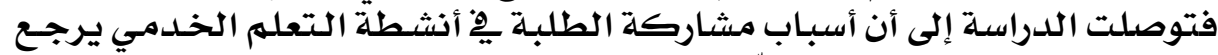

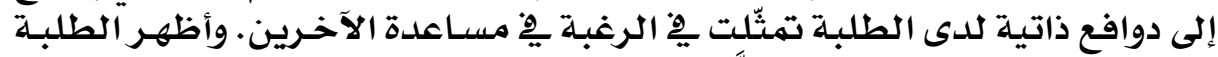

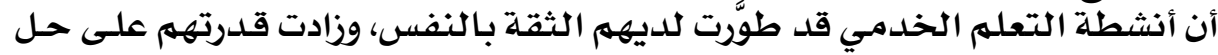

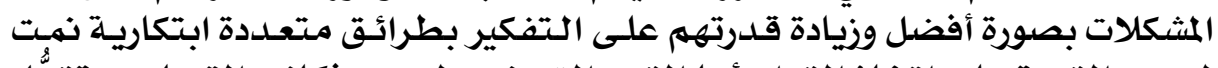

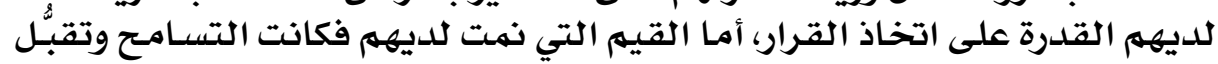

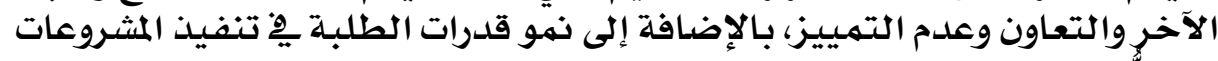

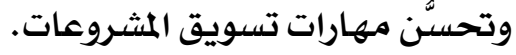

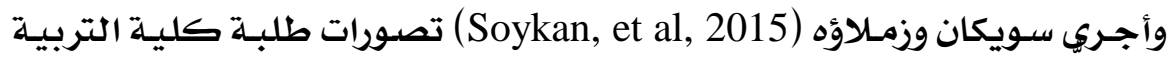

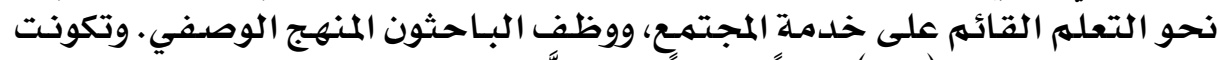

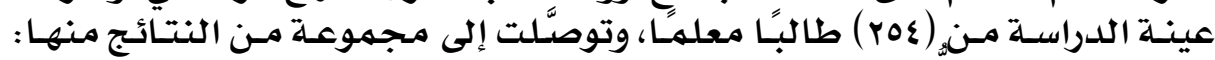

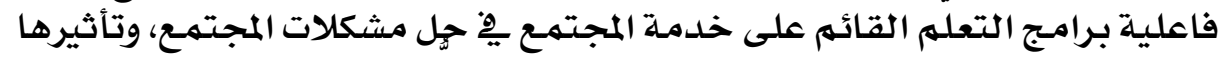

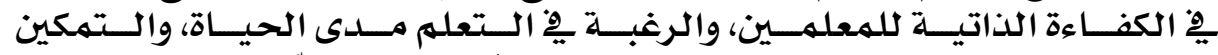

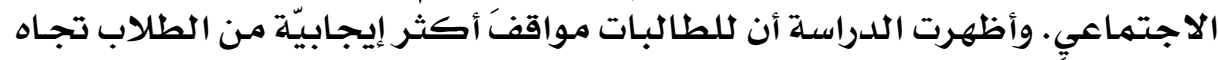

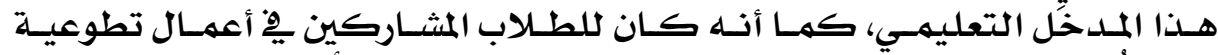

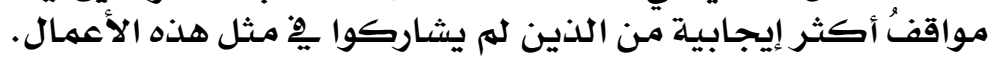

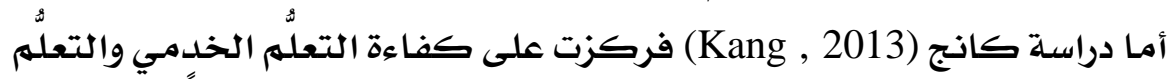

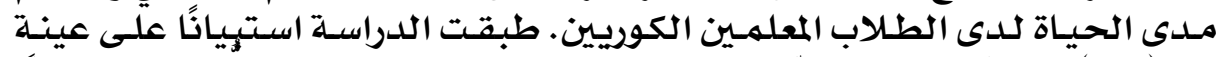

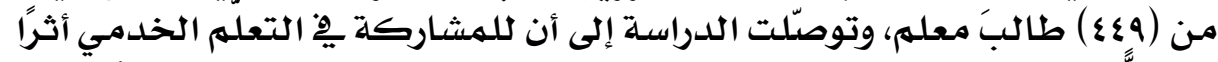

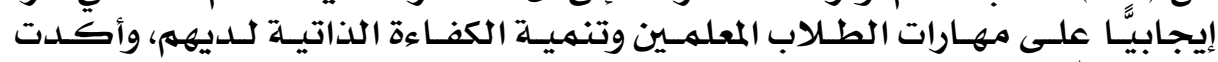

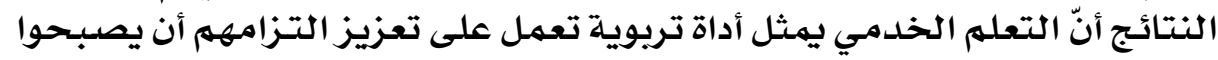

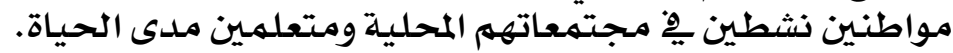

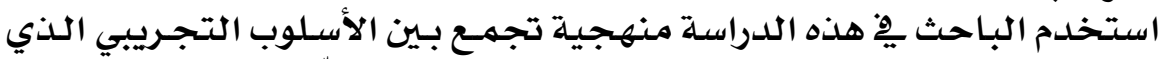

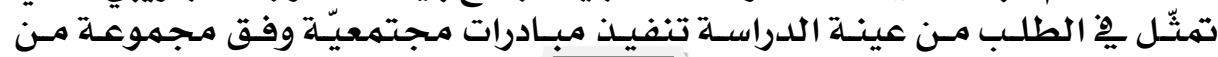

\section{\& 7}




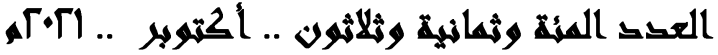

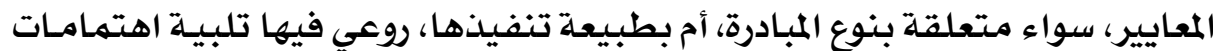

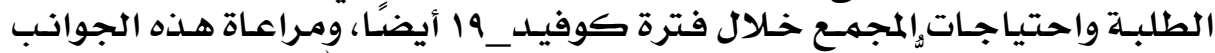

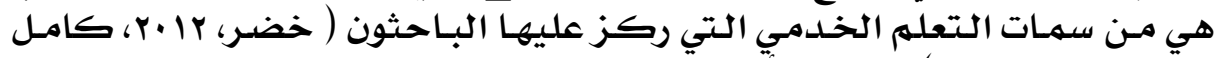

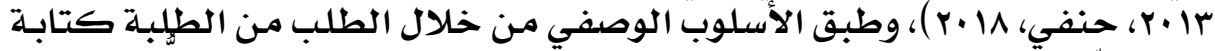

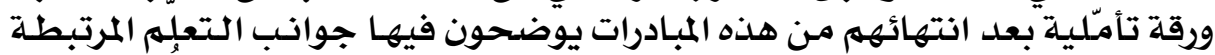

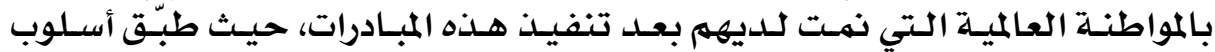

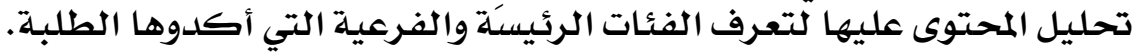

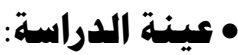

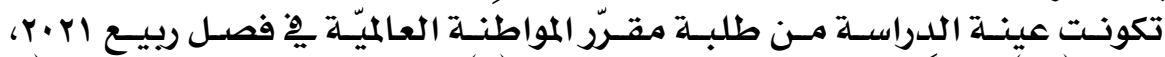

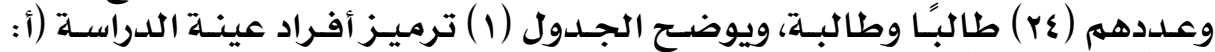

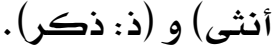

جدول (1): ترميز عينت الدراست:

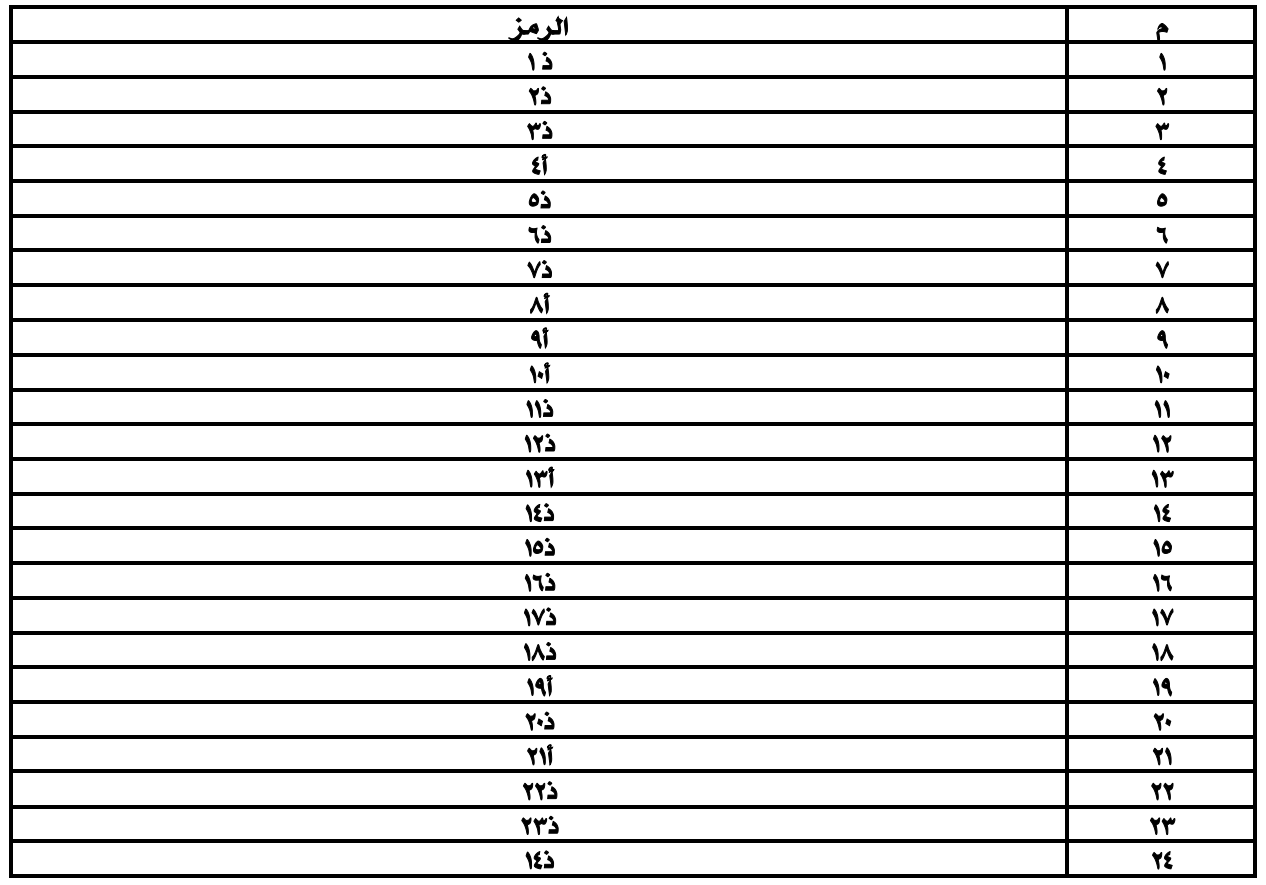

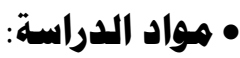

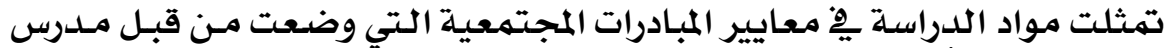

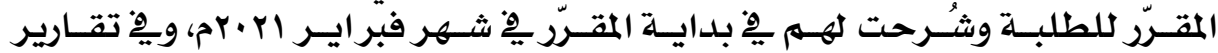

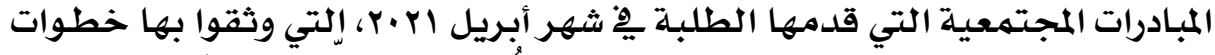

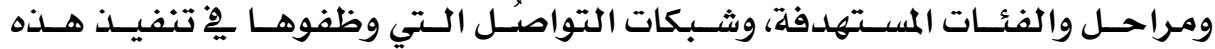




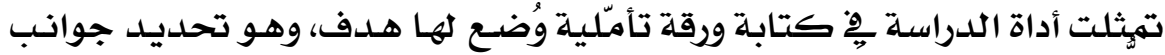

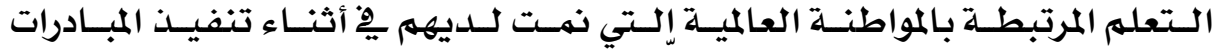

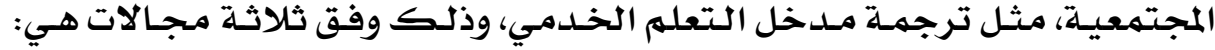

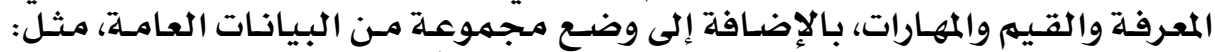

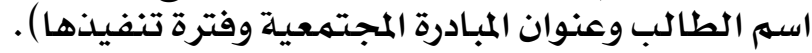

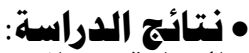

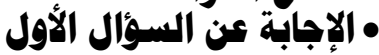

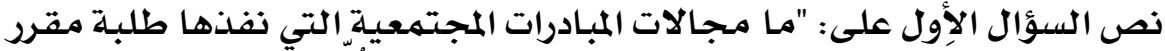

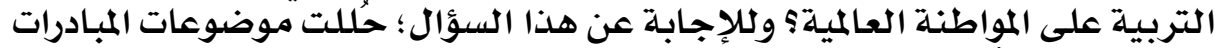

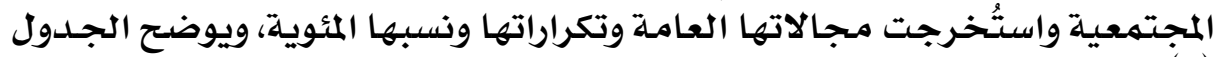
ن

جدول (r): مججالات المبادرات المجتمعيت التي ثفذها طلبت مقرّز التربيت على المواطنَت العالميت:

\begin{tabular}{|c|c|c|c|c|c|}
\hline النسيتي & التكراد & محال المبادرة & ثوع المبادرة & الرمز & \\
\hline \multirow[t]{7}{*}{ Y9.17 } & \multirow{7}{*}{$v$} & صحصى & مبادرة عن الوعى بلقاحات كوفيد 19. & $1 j$ & \multirow{7}{*}{ المجال الأول } \\
\hline & & صحصى & التوعيت بلقاح كوفيل 19. & \multirow{2}{*}{ ذ' ذד } & \\
\hline & & صحي & مبرض مبادرة ركزت على الجاثب الصحي والتثقيف الصحي من & & \\
\hline & & 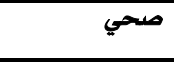 & 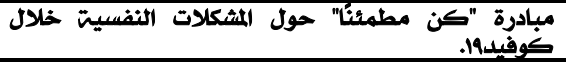 & vj & \\
\hline & & صحصى & التوعيت باللقاحات. & IYj & \\
\hline & & صححي & 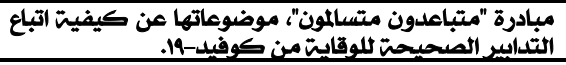 & 10ذ & \\
\hline & & صحي & مبادرة الاجتباعلدون متسالمون"، وموضوعها حول اهميتً & Y.j & \\
\hline \multirow[t]{5}{*}{$r \cdot A r$} & \multirow[t]{5}{*}{ - } & خيري & توفير وجبات إفطار للعمالت الوافلة. & Ir j & \multirow{5}{*}{ المجال الثاني } \\
\hline & & خيري & 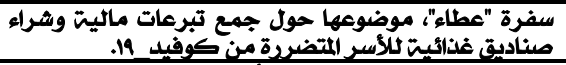 & Ai & \\
\hline & & 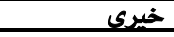 & حصالة "قريتي"، جمـع تبرعات لأهل القريتش. & iri & \\
\hline & & خيري & كيدًا بيد المساعدة الأيتام المتضررين من جائحت كورونا، & 17j & \\
\hline & & خيرى & كسوة العيل. & 191 & \\
\hline \multirow[t]{3}{*}{ ir.० } & \multirow{3}{*}{$r$} & رياضي & الرياضتش 2 ظل جائحت كورونا. & 1\&j & \multirow[t]{3}{*}{ 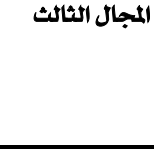 } \\
\hline & & رياضي & 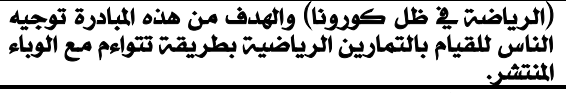 & Mj & \\
\hline & & رياضغ & الرياضتش2 كوفيل 19. & Y & \\
\hline \multirow[t]{3}{*}{ ir.o } & \multirow{3}{*}{$r$} & فكري معلوماتى & نشر الومى بالشائعات التى صاحبت صوفيد19. & ذ & \multirow[t]{3}{*}{ المجال الرابع } \\
\hline & & فكري معلوماتي & الثبادرة "كن مطمئناً"، تهدف إلى بث الروح المعنويت ودحض & IVj & \\
\hline & & فكري معلوماتي & 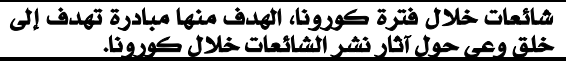 & ry & \\
\hline \multirow[t]{2}{*}{ A.rr } & \multirow[b]{2}{*}{ r } & فثى & رسائل من خلال الفن حول معالحت قضايا كوفيل 19. & 91 & \multirow[t]{2}{*}{ المجال الخامس } \\
\hline & & فني & معرفيد 19. فني افتراضي لبعض اللوحات المتعلقت بمرض & 1.1 & \\
\hline \multirow[t]{2}{*}{ A.rr } & \multirow[t]{2}{*}{ r } & ثقليِ اجتمامي & ومائحتَ كوضوفيد 19. الاستفادة من تجارب الآخرين يُ ظل & ذ11 & \multirow[t]{2}{*}{ المجال السادس } \\
\hline & & ثقلية تعليمى & 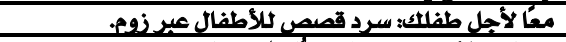 & 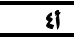 & \\
\hline$\varepsilon .17$ & 1 & توعوىى & حساب 2: أحلد مواقع التواصلُ الاحتماعى. & IEj & المحال السعابع \\
\hline$\varepsilon .17$ & 1 & نفسي & 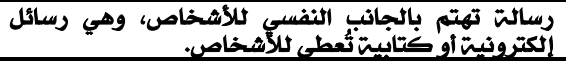 & YII & المجال الثثامن \\
\hline $99.9 \mathrm{~V}$ & $Y \varepsilon$ & & & & المحموع \\
\hline
\end{tabular}




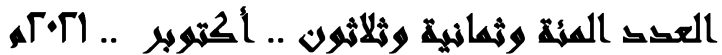

يتضح من الجلدول (r) أن المبادرات التي نفذها أفراد العينـة توزعت على ثماتى ثمانيـة

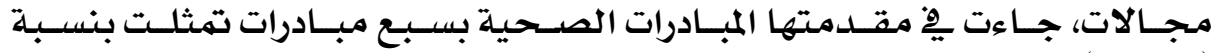

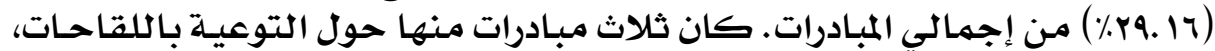

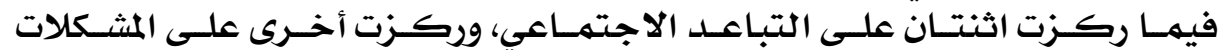

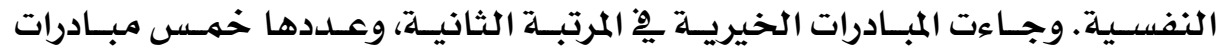

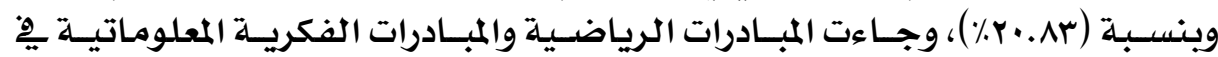

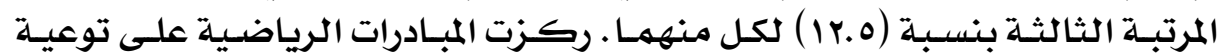

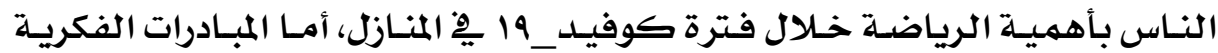

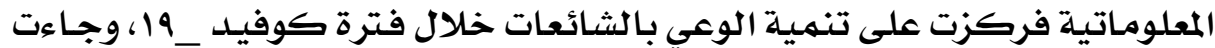

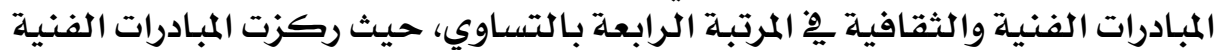

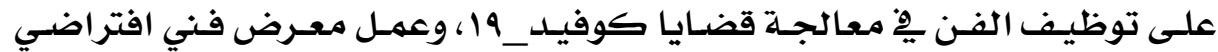

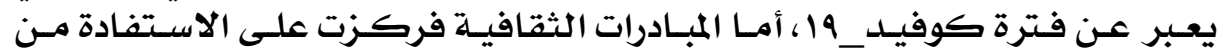

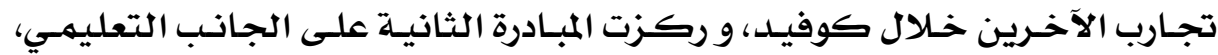

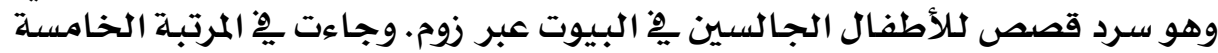

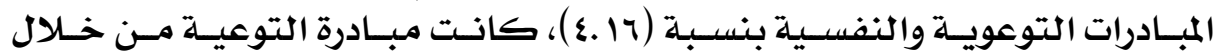

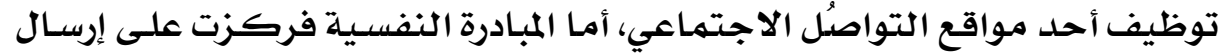

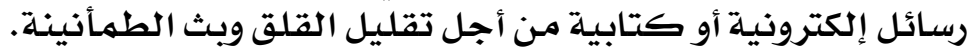

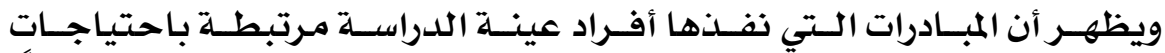

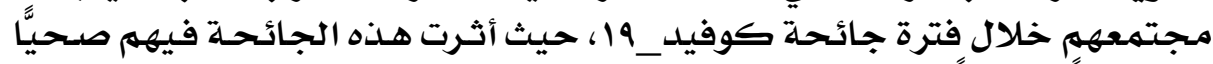

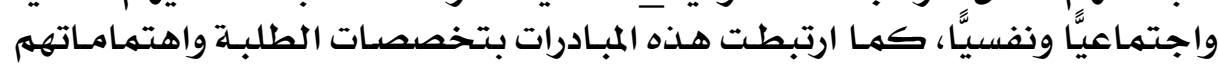

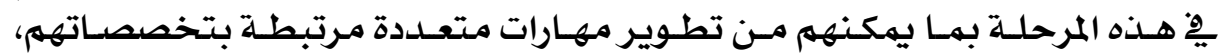

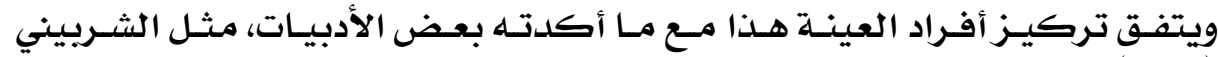

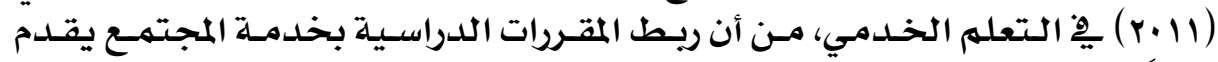

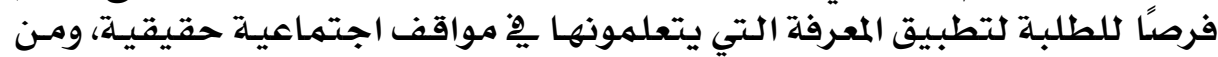

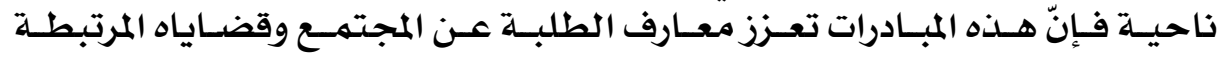

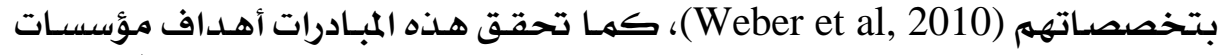

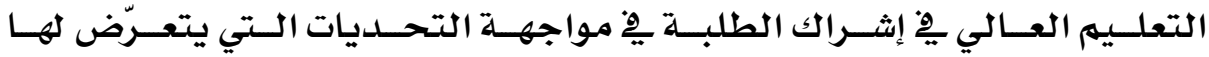

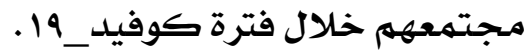

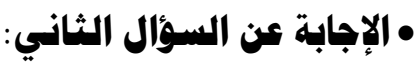

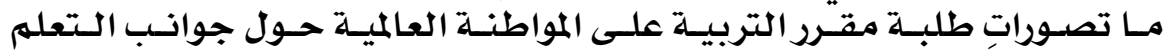

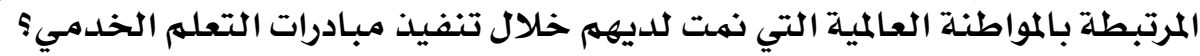

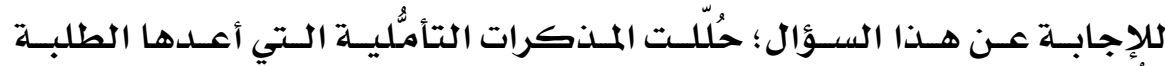

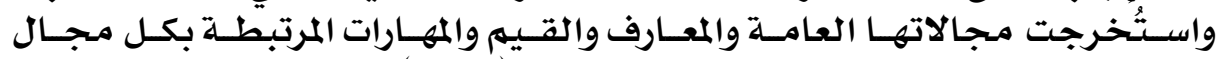

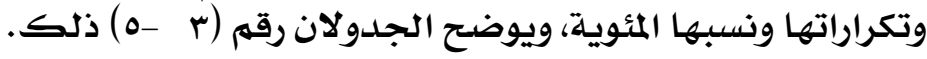

\section{$\varepsilon q$}




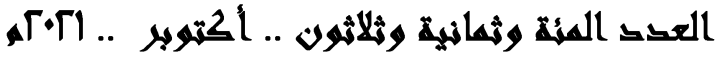

• أولا- المجال المعرفي: : جلمار): المعارف التي اكتسبها أفراد عينت الدراست من تنفيذ المبادرات المجتمعيت:

\begin{tabular}{|c|c|c|c|c|}
\hline النسبت & 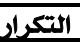 & لمعارف التى اكتسبها أفراد العينت من عمل الميادرة & الرمز & \\
\hline \multirow[t]{7}{*}{$r \varepsilon$} & \multirow[t]{7}{*}{ ir } & 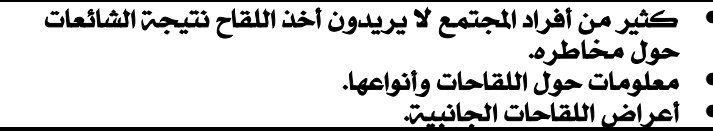 & ij & \multirow[t]{7}{*}{ ألمجال } \\
\hline & & 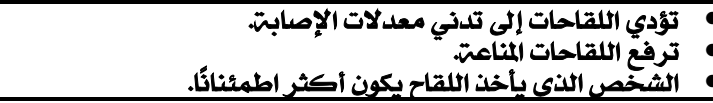 & ذا & \\
\hline & & أهميت التثقيف الصحى بـ التقليل من الإصابات. & ذד & \\
\hline & & 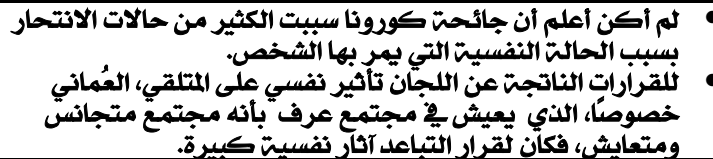 & vi & \\
\hline & & 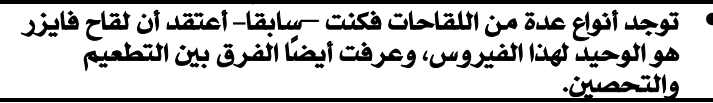 & ذ'r & \\
\hline & & 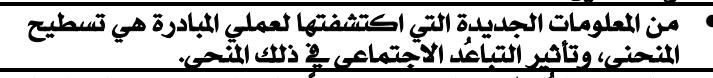 & ذ10 & \\
\hline & & 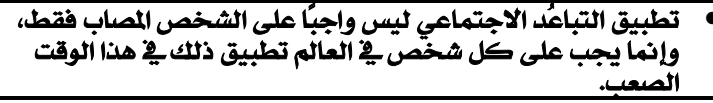 & ذبن & \\
\hline \multirow[t]{5}{*}{10} & \multirow[t]{5}{*}{7} & 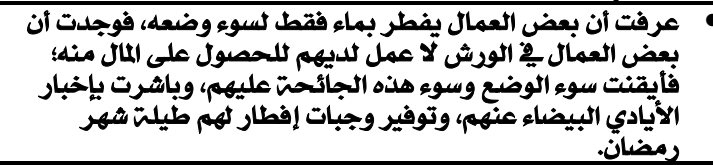 & נזri & \multirow[t]{5}{*}{ ألجخيري } \\
\hline & & 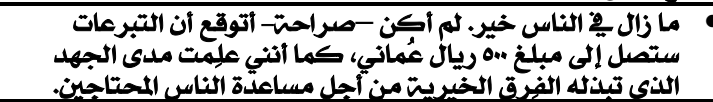 & NI & \\
\hline & & 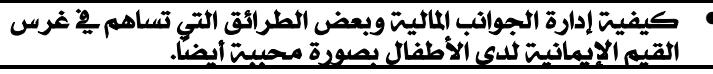 & וr & \\
\hline & & 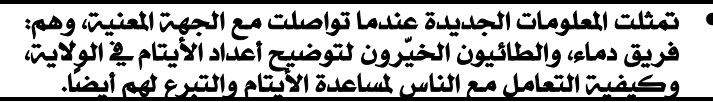 & נדו & \\
\hline & & 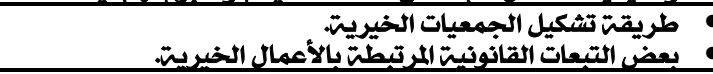 & 191 & \\
\hline \multirow[t]{3}{*}{$r$} & \multirow[t]{3}{*}{$\wedge$} & 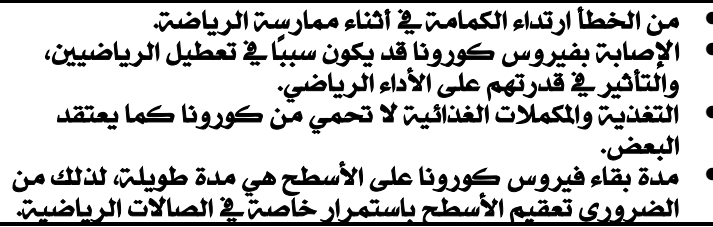 & Y\& & \multirow[t]{3}{*}{ 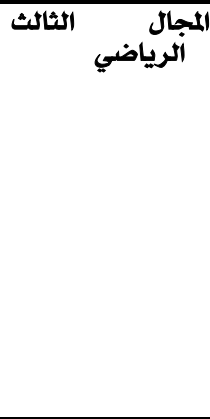 } \\
\hline & & 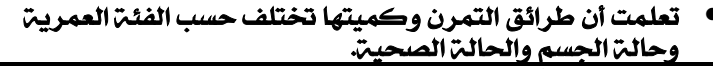 & ذ内 & \\
\hline & & 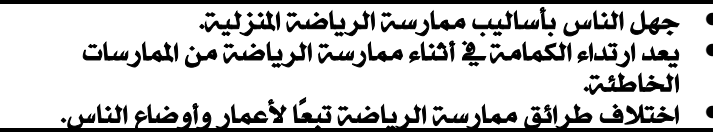 & 广j & \\
\hline \multirow[t]{2}{*}{ ir } & \multirow[b]{2}{*}{ • } & للشائعات أثر ف الفرد، ويؤدي إلى القلق والذنعر. & ذه & \multirow{2}{*}{ ألجال المكري } \\
\hline & & 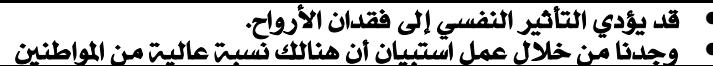 & IVj & \\
\hline
\end{tabular}

\section{$\theta$.}




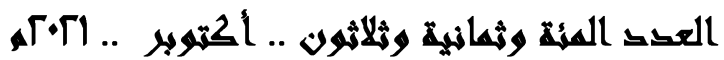

\begin{tabular}{|c|c|c|c|c|}
\hline & & 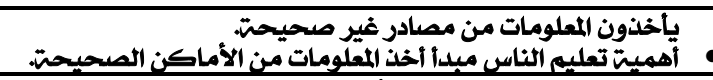 & & \\
\hline & & 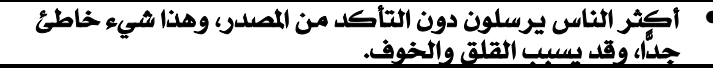 & Ir & \\
\hline \multirow[t]{2}{*}{0} & $r$ & 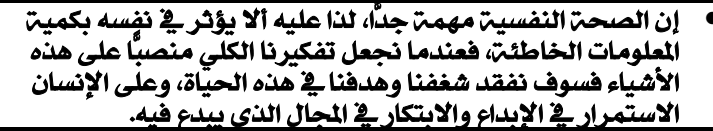 & 91 & \multirow[t]{2}{*}{ ألجزال } \\
\hline & & 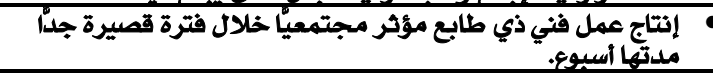 & 1.1 & \\
\hline \multirow[t]{2}{*}{$\wedge$} & \multirow[t]{2}{*}{$r$} & 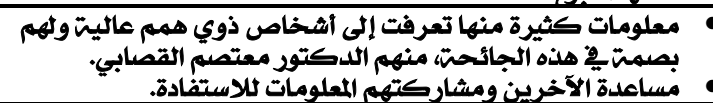 & ذו & \multirow[t]{2}{*}{ الألثقليّ: } \\
\hline & & • مشاهدتهاً. & \& & \\
\hline r & 1 & الناس أكثر تفاعلا على منصات التواصُل الاجتماعي. & ذ1 & المجلوئوي \\
\hline r & 1 & 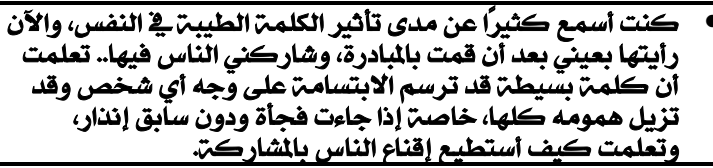 & rII & ألمجال المسي الثامن \\
\hline
\end{tabular}

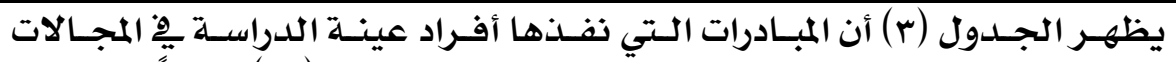

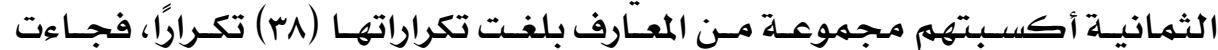

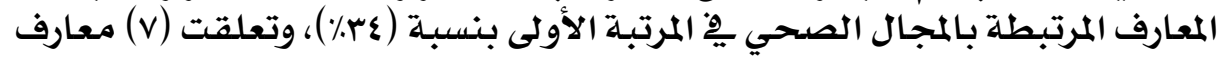

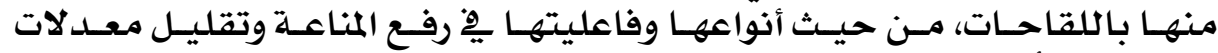

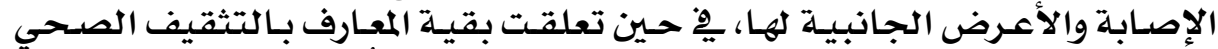

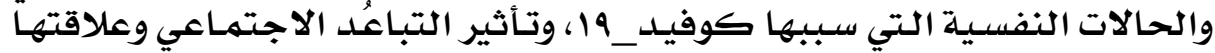

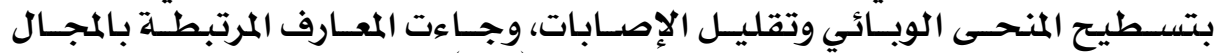

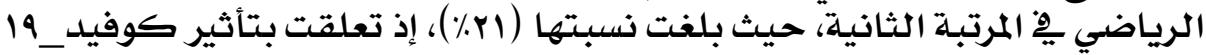

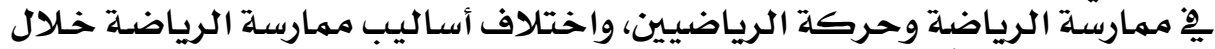

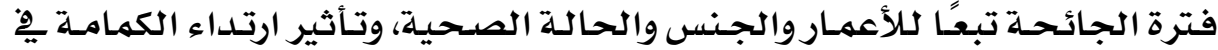

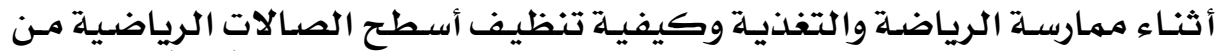

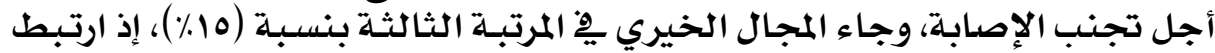

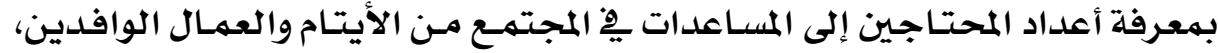

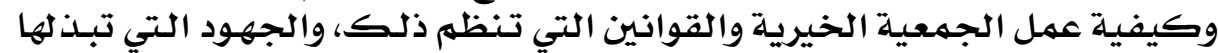

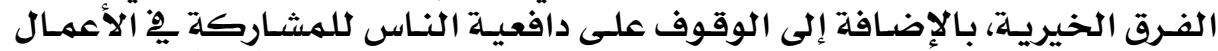

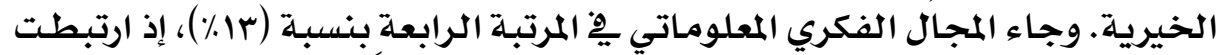

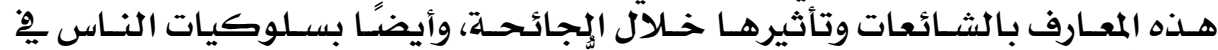

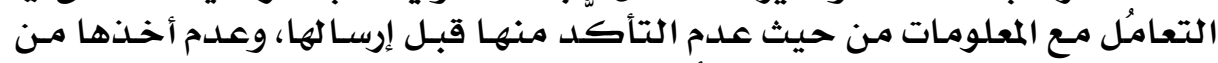

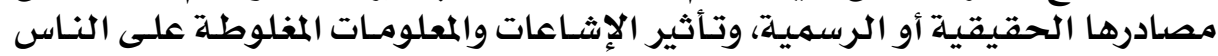

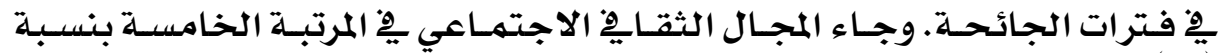

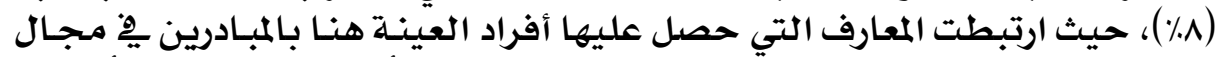

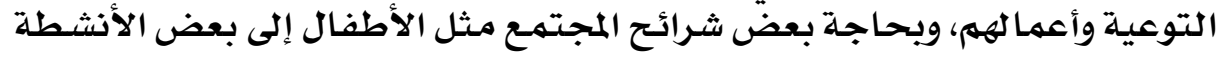

\section{1}




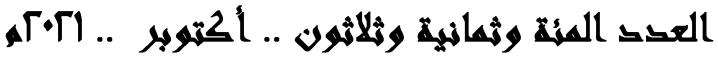

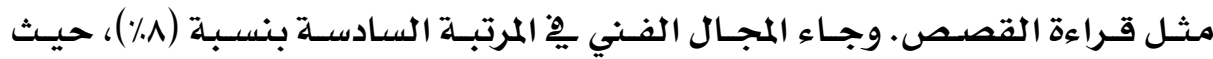

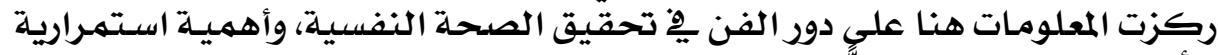

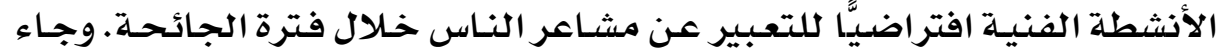

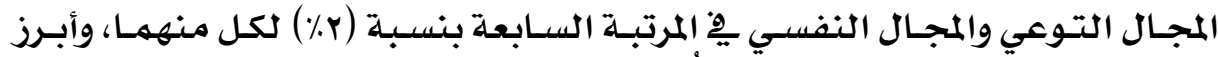

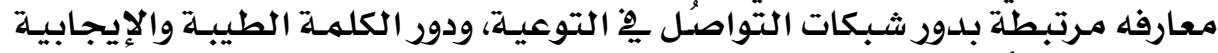

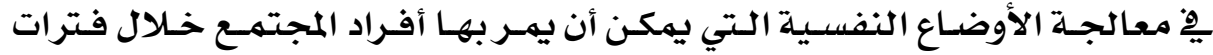
الجوائح. معاج.

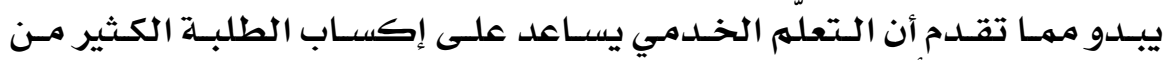

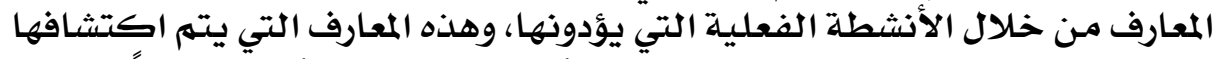

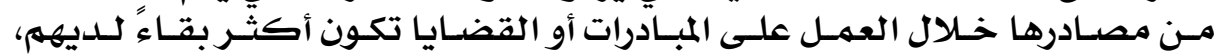

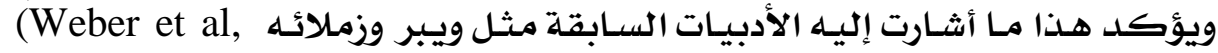

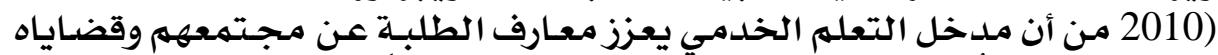

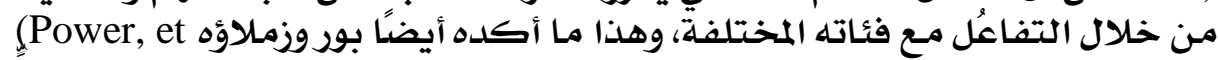

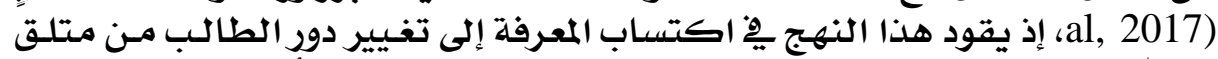

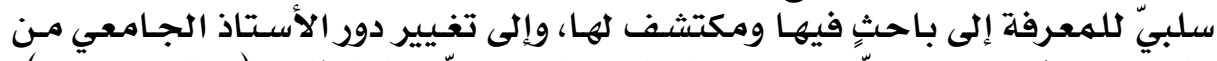

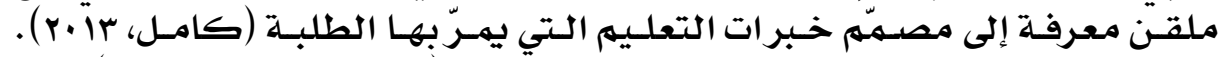

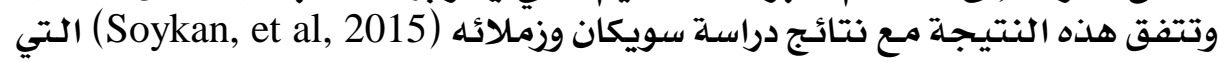

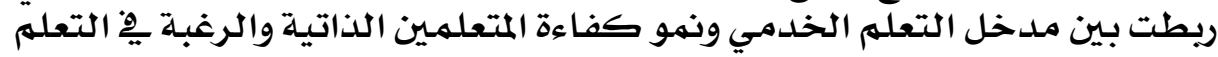
مدى الحياة.

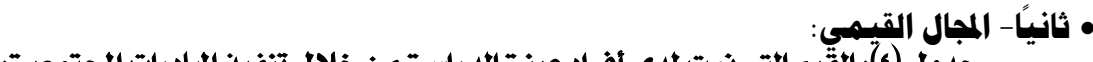
جذول (ع): القيميم التي نمت لدى أفراد عينت الدراست من خلال تنفيذ المبادرات المجتمعيت:

\begin{tabular}{|c|c|c|c|}
\hline النسبت & 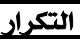 & القيم الاجتماعيت. & 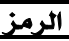 \\
\hline \multirow[t]{10}{*}{ r.vo } & \multirow[t]{10}{*}{11} & التعاون. & $-1 ذ$ \\
\hline & & روح التعاون. & \&ा \\
\hline & & قيمت التعاون، لأننى تعاونت مع زملائى يخ المبادرة والابتكار. & ذه \\
\hline & & التعاون مع أفراد المجتمع لسلد احتياجاتنا جميعًا. & AI \\
\hline & & العمل معاً لجميع أفراد المحتمع هُ الأوقات الصعبت. & Irj \\
\hline & & التعاون. & 1\&ذ \\
\hline & & التعاون. & וזו \\
\hline & & التعاون لمساعدتهم ولو قليلا. & rrj \\
\hline & & التعاون بين أفراد المحتمع. & rYj \\
\hline & & التعاون بينى ويين زملائى والمساواة. & Yذj \\
\hline \multirow[t]{5}{*}{$9.2 \%$} & \multirow[t]{5}{*}{ • } & التكاتف. & ذا- \\
\hline & & التكاتف. & i \\
\hline & & التكافل الاجتماعى. & AI \\
\hline & & الشعور بالغير عن طريق التكافل. & rrj \\
\hline & & تعزيز روح الألفتّوالحب والوئام بين أفراد المجتمع. & ذ17 \\
\hline \multirow[t]{5}{*}{$9.8 r$} & \multirow[t]{5}{*}{ • } & مساثدة الناس. & Y ذ \\
\hline & & مساعدة الآخرين. & 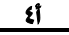 \\
\hline & & مساعلدة الناس والوقوف إلى جانبهم وتلبيت احتياجاتهم. & Vj \\
\hline & & مساعلدة الآخرين ومشار كتهم بالمعلومات للاستقادة. & II \\
\hline & & مساعلدة الناس وإسعادهم. . م & 199 \\
\hline 1.11 & 1 & قيم النصح والإرثاد لأفراد المحتمع لاتباع التدابير الصحيتة. & ذ \\
\hline
\end{tabular}

\section{OY}




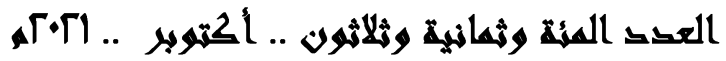

\begin{tabular}{|c|c|c|c|}
\hline 1.11 & 1 & العطف على الفقراء والمساكين والمحتاجين. & 17 \\
\hline 1.11 & 1 & |لالتزام بالسلام. & Mذ \\
\hline 1.11 & 1 & إسعاد قلوب الناس. & ril \\
\hline \multirow[t]{2}{*}{$\varepsilon V .17$} & ro & المجموع & \\
\hline & & قيم المواطنت & \\
\hline \multirow[t]{7}{*}{ Ir.Y. } & \multirow[t]{7}{*}{ 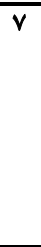 } & الانتماء الايحليع إلى المحتمع. & Yj \\
\hline & & الانتماء إلى المجتمع. & 1.1 \\
\hline & & إرثاد الناس إلى خطورة علدم التباعُد الاجتماعى. & r.j \\
\hline & & مشاركت الغير 22 التوعيت والنصح ومحاريت الشائعات. & Iri \\
\hline & & التنميت والخير لكل أفراد المحتمع. & $17 \dot{3}$ \\
\hline & & التعايشي المشترك مـع الآخرين، فلا يهم جنسه أو لوثه. & ذוr \\
\hline & & تقدير التنوع 2: المحتمع. & 1.1 \\
\hline \multirow[t]{4}{*}{ v.0\& } & \multirow[t]{4}{*}{$\varepsilon$} & حقوق الإنسان فِ الحصول على حياة كريمتروزاهيت والكيش الكريم. & vi \\
\hline & & 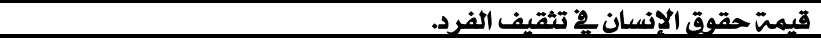 & ذه \\
\hline & & 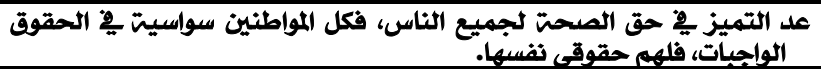 & IVI \\
\hline & & العدالت والمساواة والبعلد عن الاهتمام بنفسى وبدائرة عائلتى فقط. & נז's \\
\hline \multirow[t]{3}{*}{0.77} & \multirow[t]{3}{*}{$r$} & الحفاظ على الصحتة. . & ri \\
\hline & & الالتزام بالإجراءات الصحيت. & $r \cdot \dot{j}$ \\
\hline & & احتراموتقدير الطاقم الطيى. & r.j \\
\hline \multirow[t]{3}{*}{0.77} & \multirow[t]{3}{*}{$r$} & مسؤوليت النظر إلى المصلحت العامتة. & ذ \\
\hline & & المساعدة على تفادي الوطن للكوارث الصحيت والأزمات. & ذוr \\
\hline & & المساهمت ـ 2 حل بعض مشكلات المحتمع. & أسו \\
\hline \multirow[t]{2}{*}{ rY.+T } & IV & المحموع & \\
\hline & & القيم الشخصيت & \\
\hline \multirow[t]{3}{*}{0.17} & \multirow[t]{3}{*}{$r$} & الميادرة الفرديت. & ذ \\
\hline & & الاستعداد للعمل. & ذ \\
\hline & & الميادرة. & ril \\
\hline \multirow[t]{3}{*}{0.74} & \multirow[t]{3}{*}{$r$} & التواصل مـ الآخرين. & ril \\
\hline & & التواصل الفعال. . & Y\&j \\
\hline & & الحوار & i \\
\hline \multirow[t]{4}{*}{ v.0\& } & \multirow[t]{4}{*}{$\varepsilon$} & والعقل المنفتح للسعى لاصعلاح المحتمع. & ذ \\
\hline & & التفكير الإبداعى. & AI \\
\hline & & الابتكار ف2 توصيل المعلومتش. & Mذ \\
\hline & & الفكر الخخلاق. & $r \varepsilon j$ \\
\hline 1.11 & 1 & الاجتهاد والسعى وعدم الياسس. & נi \\
\hline \multirow[t]{2}{*}{ Y.VE } & 11 & المحموع & \\
\hline & or & المحموع الكلى & \\
\hline
\end{tabular}

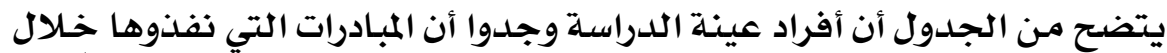

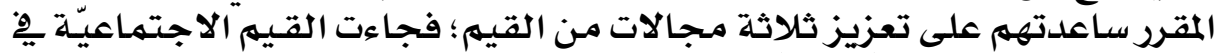

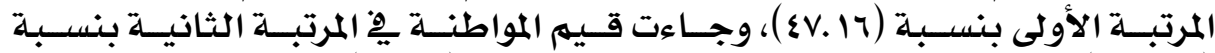

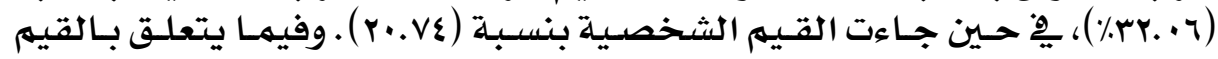

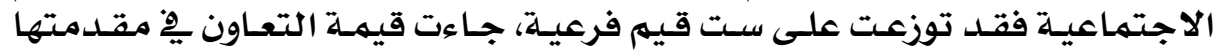

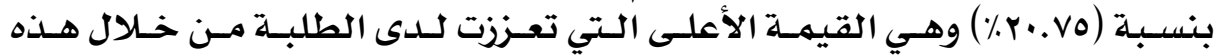

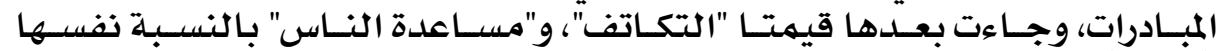

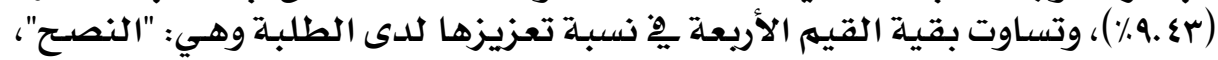

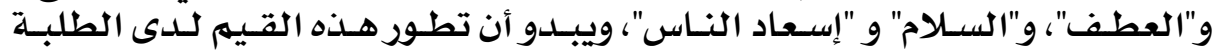

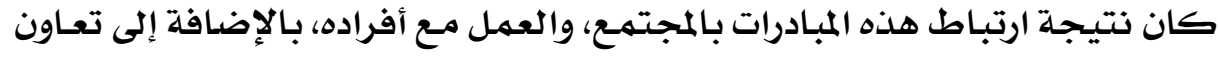

\section{$\theta Y$}




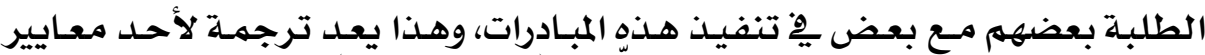

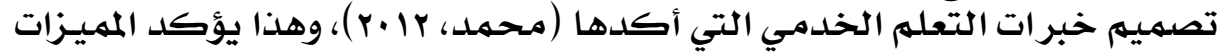

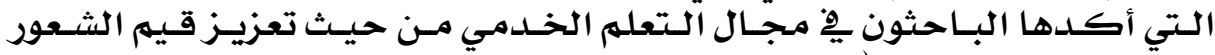
بالمسئولية الاجتهاعية (Xu, 2010).

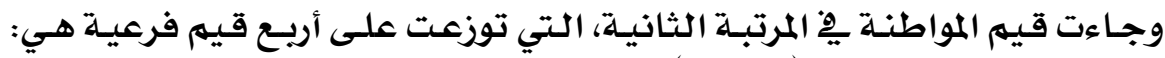

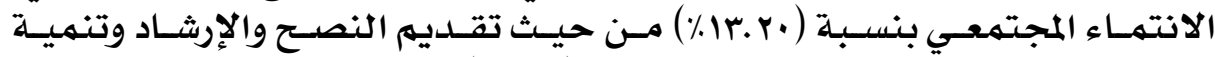

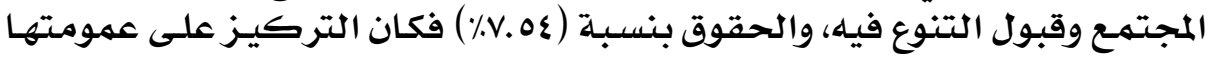

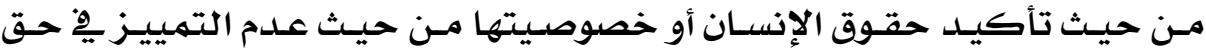

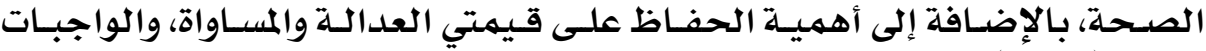

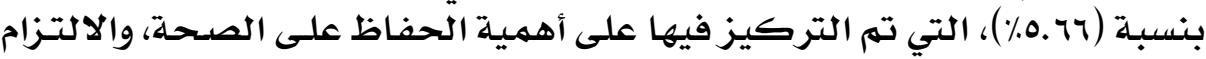

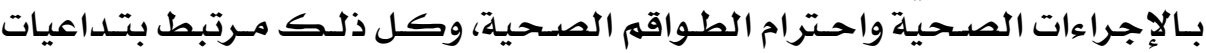

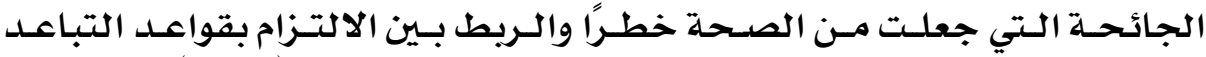

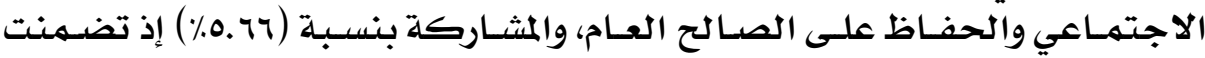

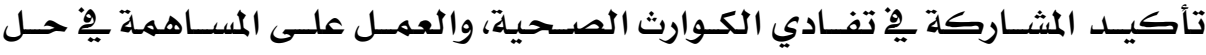

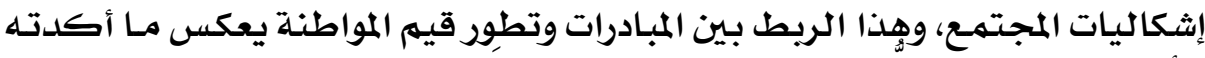

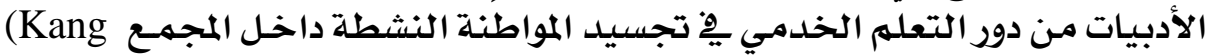

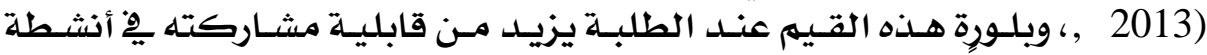

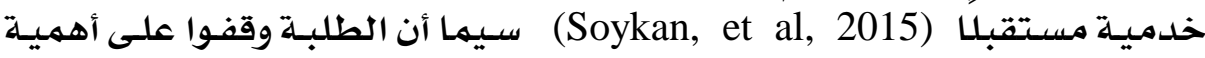

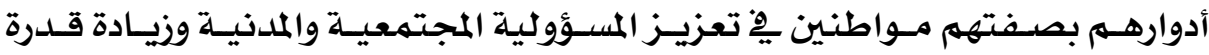

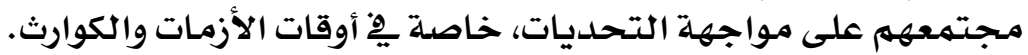

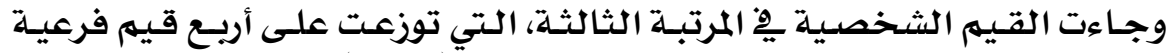

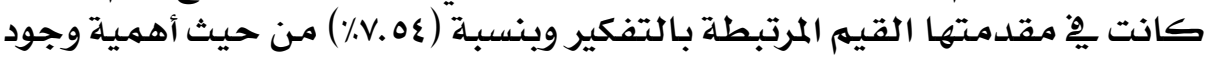

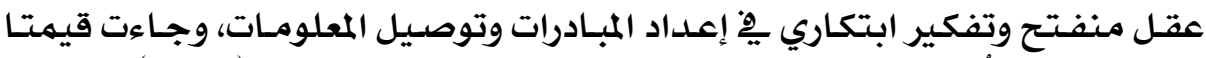

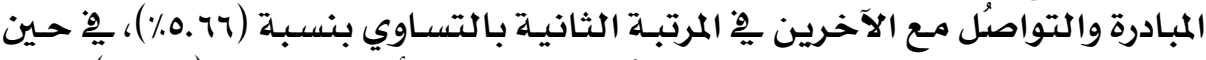

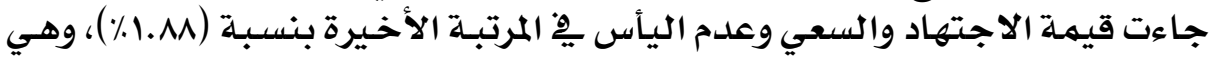

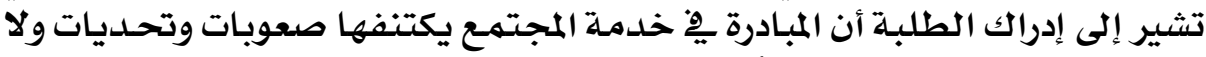

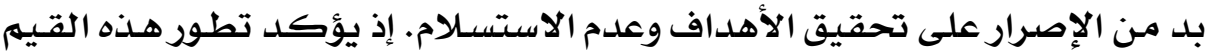

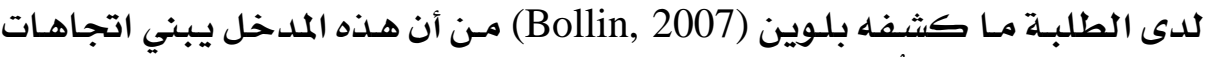

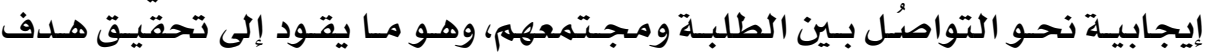

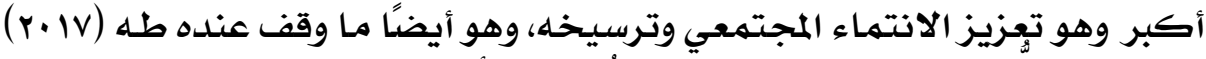

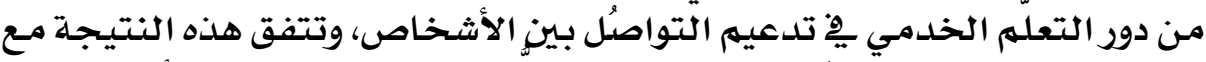

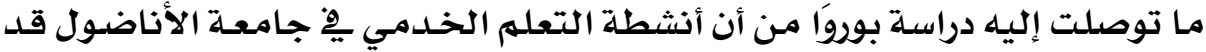

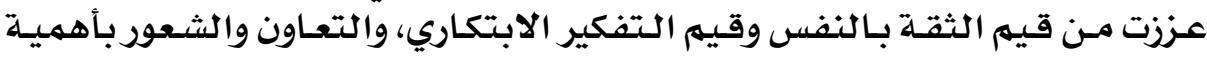

\section{$\odot \varepsilon$}




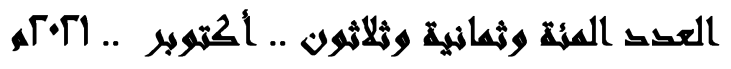

• ثالثًا - المجال المهاري:

جذول (ه): المهتارات التي نمت للى أفراد عينت الدراست من خلال تنفيذ المبادرات المجتمعيت:

\begin{tabular}{|c|c|c|c|}
\hline النسبية & التكراد & \multirow{2}{*}{\multicolumn{2}{|c|}{ 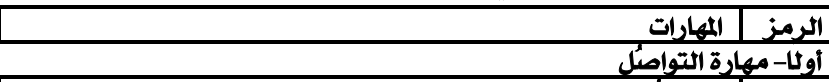 }} \\
\hline & & & \\
\hline \multirow[t]{10}{*}{ IV.YE } & \multirow[t]{10}{*}{ 1. } & التواصلُ مع المجتمع. & ij \\
\hline & & البحث والاستماع للناس. & 立 \\
\hline & & التواصُل م-ع الحمهور وأصحاب المصلحت. & ذד \\
\hline & & مهارة التواصُُ مع الناس. & Irj \\
\hline & & 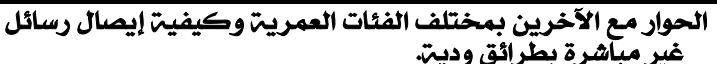 & أiा \\
\hline & & التواصلّل مع الآخرين. & $1 \varepsilon$ \\
\hline & & كيفيت التعامل وإقناع الناس ـ2 التواصُل الفعال. & ذ17 \\
\hline & & مهارات التواصُل مع الآخرين. & 191 \\
\hline & & مهارة التواصيل مع الآخرين & rif \\
\hline & & مهارة التواصِل والتفاعل مع الآخرين. & נrs \\
\hline & & \multirow{2}{*}{\multicolumn{2}{|c|}{ فانئًا- مهارة الالابتكار }} \\
\hline \multirow[t]{7}{*}{18.4} & \multirow[t]{7}{*}{$\mathrm{v}$} & & \\
\hline & & الابتكار & $r \dot{s}$ \\
\hline & & الابتكار & ذه \\
\hline & & الابتكار & iti \\
\hline & & الابتكار & ivis \\
\hline & & الابتكار & rif \\
\hline & & الابتكار & YYS \\
\hline \multicolumn{4}{|c|}{ قالثًا-التصصيم: } \\
\hline \multirow[t]{6}{*}{$1 . . \% \varepsilon$} & \multirow[t]{6}{*}{1} & تصميم موقع إلكترونى. & I \\
\hline & & تعلم تصميم قصتر رقميت. & \&1 \\
\hline & & تصميم مكنونات الميادرة. & ذَ \\
\hline & & تصميم بوسترات جيلة تجذب الناس إلى الميادرة. & Ai \\
\hline & & مهارة التصميم & rij \\
\hline & & تنميت مهاراتى ف2 التصميه. & $Y \dot{S}$ \\
\hline & & \multirow{2}{*}{\multicolumn{2}{|c|}{ 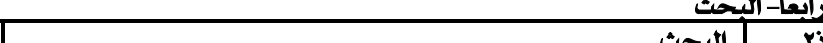 }} \\
\hline \multirow[t]{7}{*}{18.4} & \multirow[t]{7}{*}{$\mathrm{v}$} & & $r$ \\
\hline & & التعرّف إلى المعلومات من مصادرها. & i \\
\hline & & 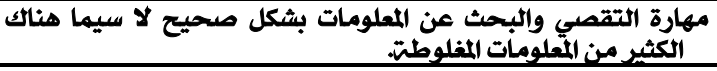 & vi \\
\hline & & البحث عن المصادر الموثوق بها للمعلومات. & Irj \\
\hline & & مهارات البحث والتقصى. & Mذ \\
\hline & & مهارة البحث عن الموضوع. & r.ذ. \\
\hline & & بحثت عن معلوما كثيرة؛ مًا أثار جاثب المعرفت وحب الاستطلاع & נS \\
\hline & & & خامسئ. \\
\hline \multirow[t]{6}{*}{$1 . \% \varepsilon$} & \multirow[t]{6}{*}{1} & القدرة على عرضها. & 1.1 \\
\hline & & تطورت للدينا مهارة العرض. & IVj \\
\hline & & التعبير وتلخيص المعلومات. & rij \\
\hline & & 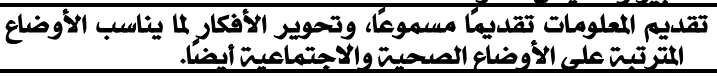 & Mذ \\
\hline & & تقديم المعلومات وعرضها بطريقت ملفتت تجلب انتباه المتابعين. & $r \varepsilon \dot{j}$ \\
\hline & & كيفيت إيصال رسائل غير مباشرة بطرائق وديتّ. & $|r|$ \\
\hline \multirow{4}{*}{$0.1 \mathrm{v}$} & & & سادسًا. \\
\hline & \multirow[t]{3}{*}{ r } & \multirow{2}{*}{ | التفكير } & iذ \\
\hline & & & $\underline{Y}$ \\
\hline & & & \\
\hline
\end{tabular}

\section{$\theta \theta$}




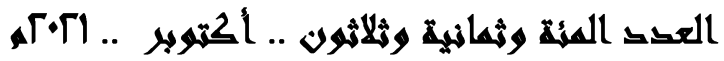

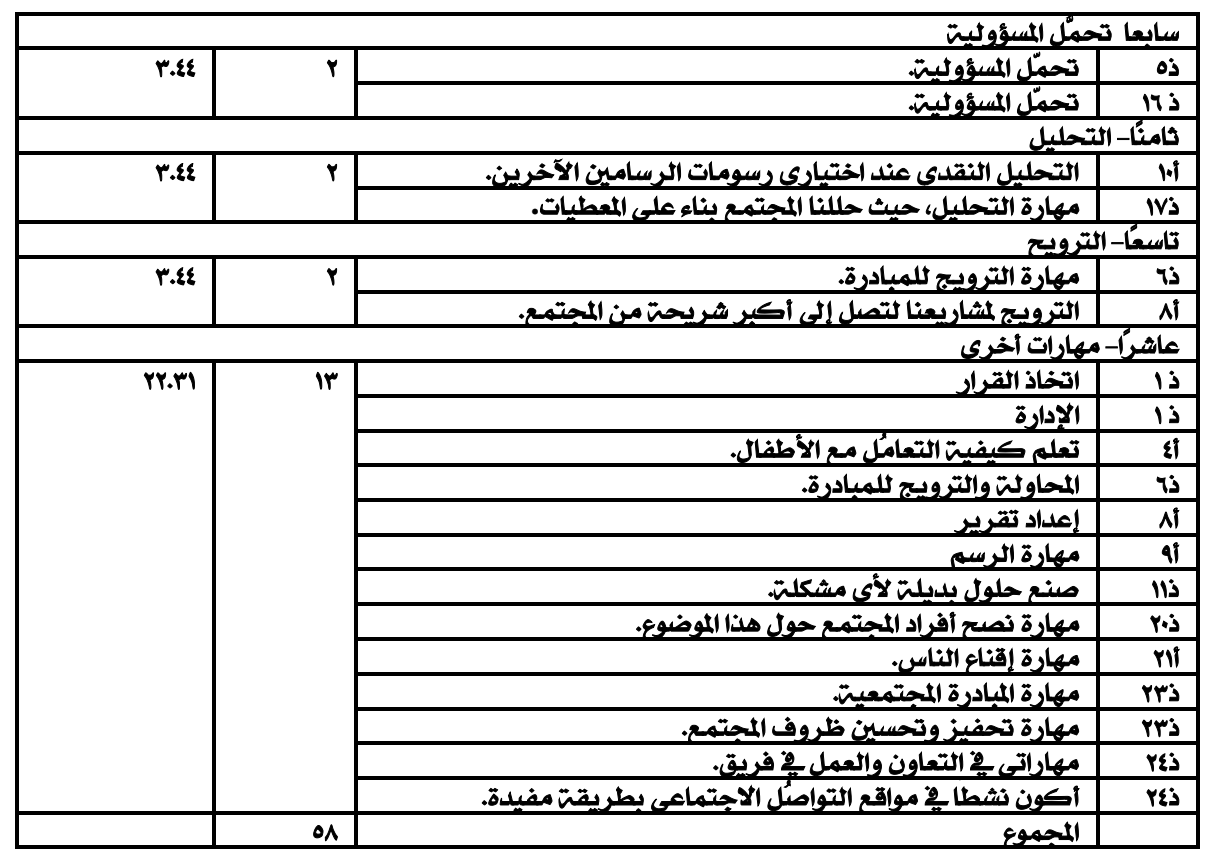

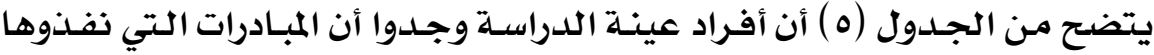

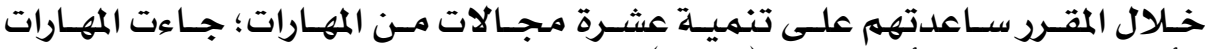

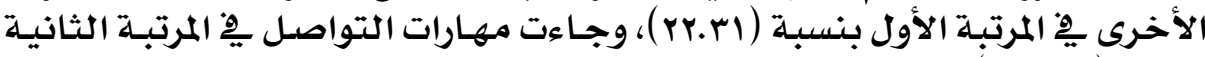

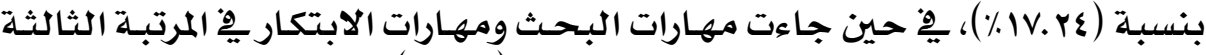

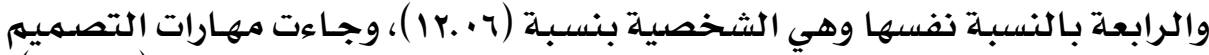

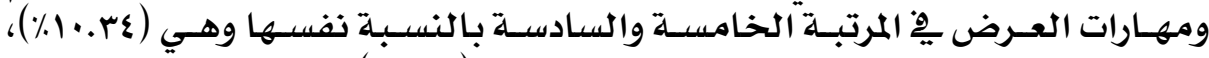

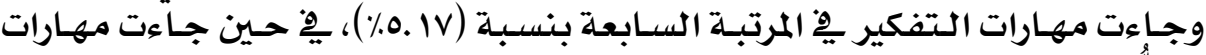

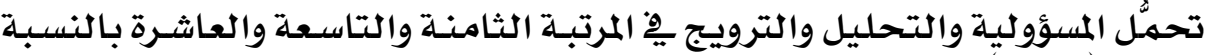

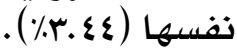

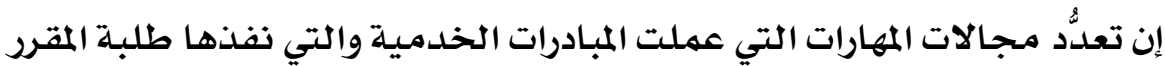

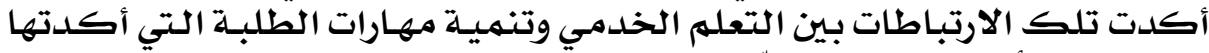

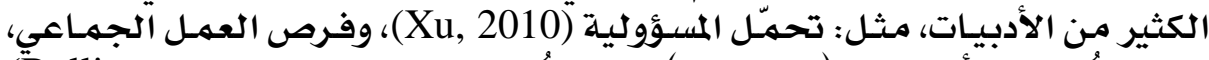

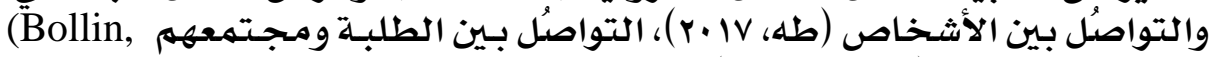

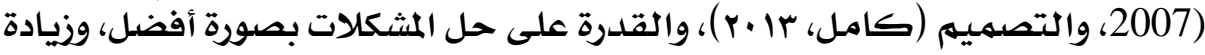

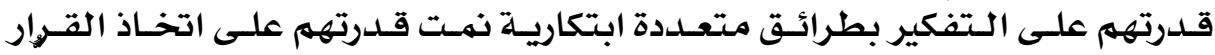

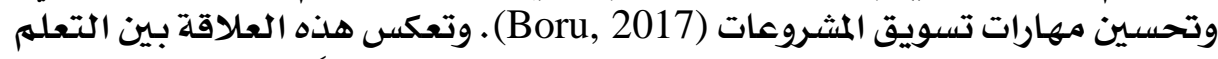

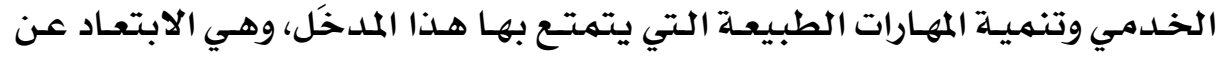

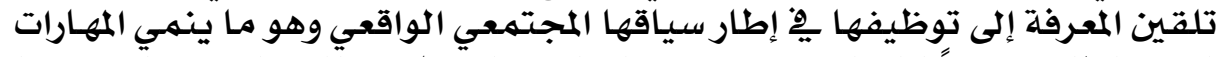

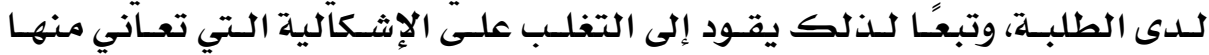

\section{7}




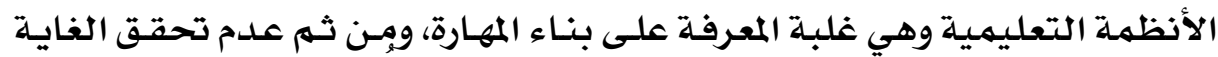

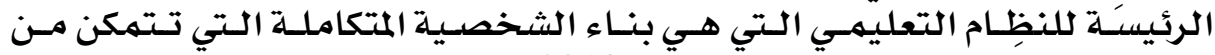

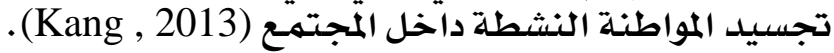

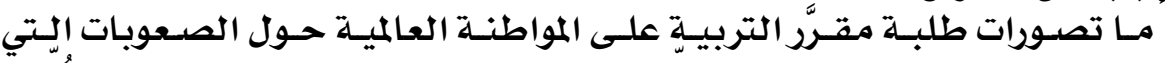

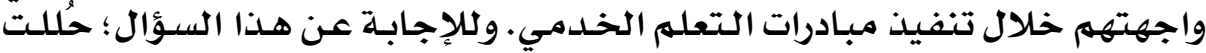

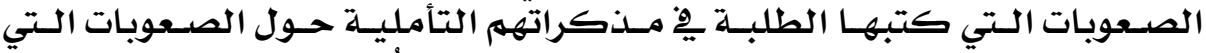

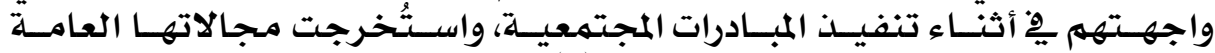

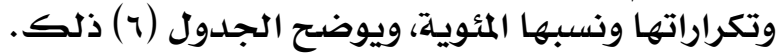

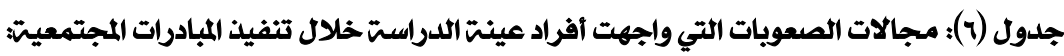

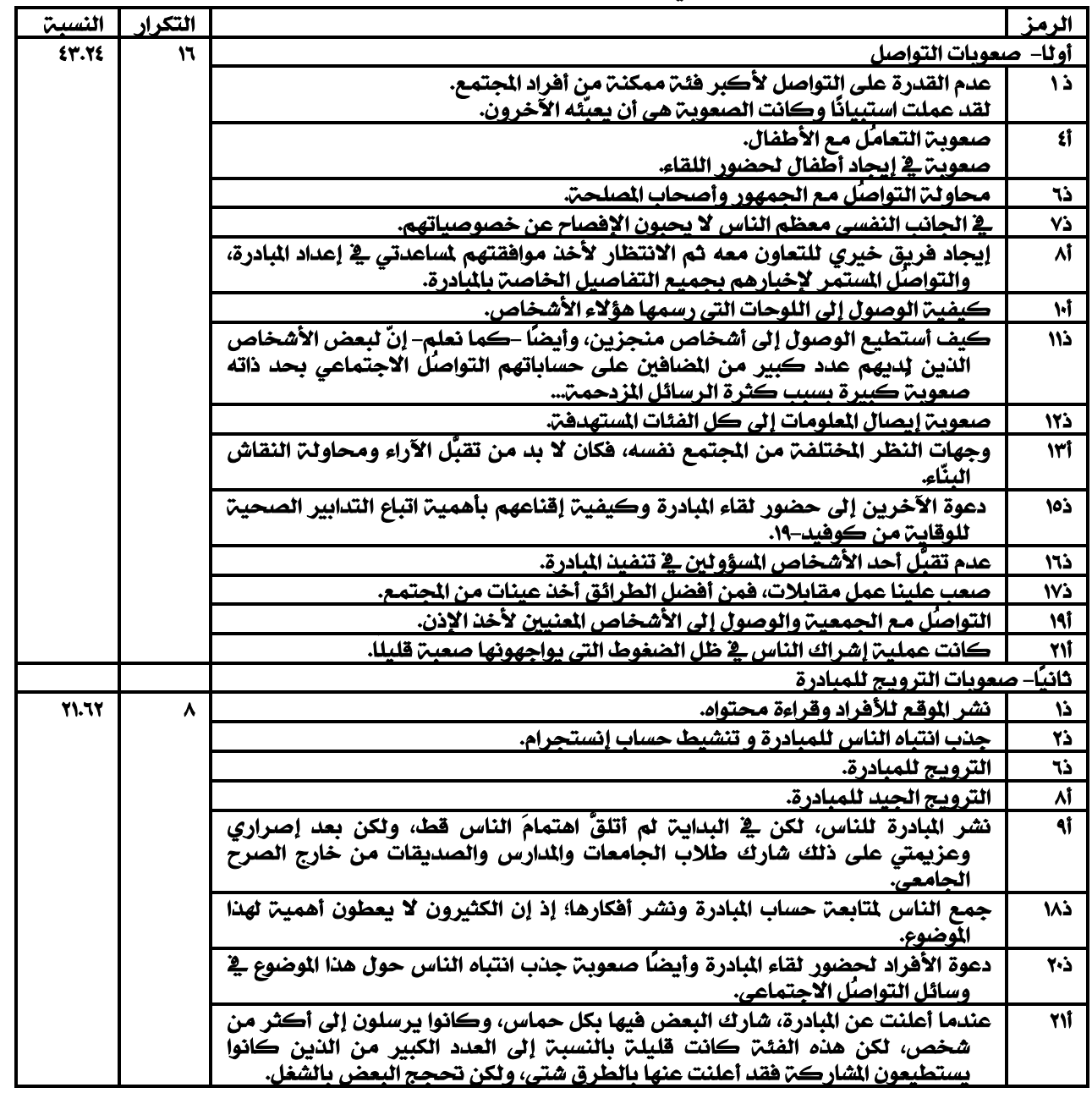

\section{$\bullet \vee$}




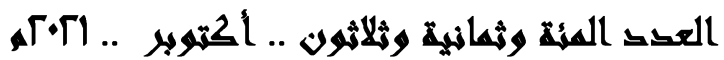

\begin{tabular}{|c|c|c|c|}
\hline & & \multicolumn{2}{|c|}{ ثالثًأ- صعويات الدعم } \\
\hline \multirow[t]{6}{*}{18.01} & \multirow[t]{5}{*}{ ० } & صعويت الحصول على الدعم، ولكن تغلبنا عليه. & ذه \\
\hline & & تلقى الدعم صعويت - 2 إيصال رسالت المبادرة لأبرز ثر يحت ممكنتة. & Vذ \\
\hline & & 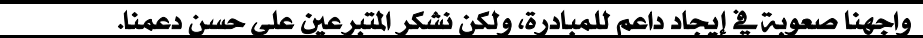 & IVj \\
\hline & & صعويت الدعم من المشاهير والتاخر 2 إلرد علينا. & ذוצ \\
\hline & & الكثير من برامج التصميم ملفوعتوفير محانيت. & ذ广 \\
\hline & & \multicolumn{2}{|c|}{ رابعًا- صعويات أخرى } \\
\hline \multirow[t]{9}{*}{ rI.TY } & \multirow[t]{8}{*}{$\Lambda$} & صعويت 2ْ تصميم القصت. & \&ा \\
\hline & & التصميه لمكنونات الميادرة. & ذף \\
\hline & & مواجعتى لاستعمال نوع جليل من الألوان لم يسبق أن استعملته من قبل. & 1.1 \\
\hline & & الأفكار المغلوطت والمترسخت لدى الناس. . المبر & Irj \\
\hline & & 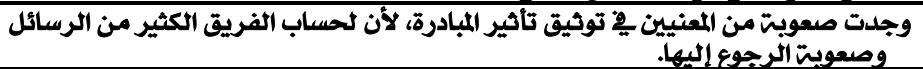 & ذ17 \\
\hline & & 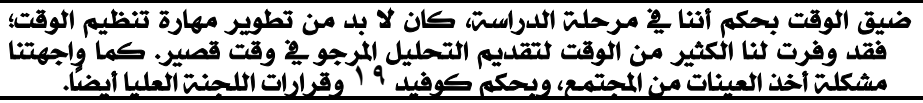 & IVנ \\
\hline & & تصوير بعض العمالت وأنا أعطيهي الوجبات، لكن بعضهم الآخر أعطيتهم دون تصوير. & 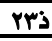 \\
\hline & & 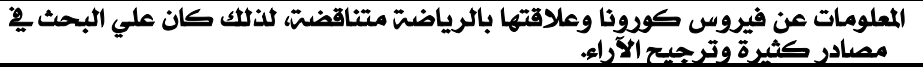 & ذ广 \\
\hline & rv & المجموع & \\
\hline
\end{tabular}

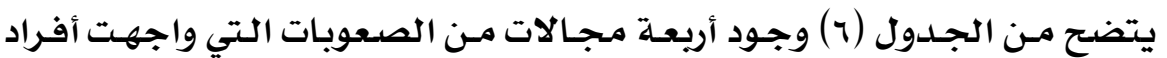

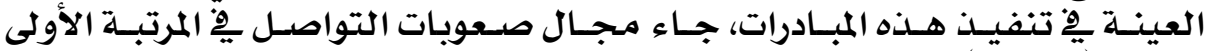

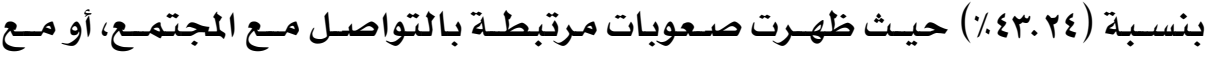

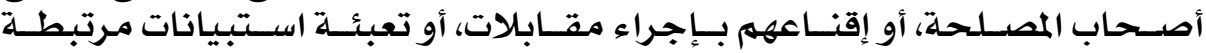

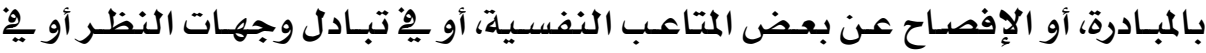

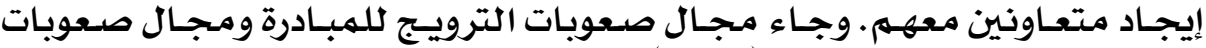

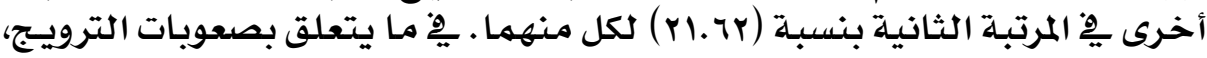

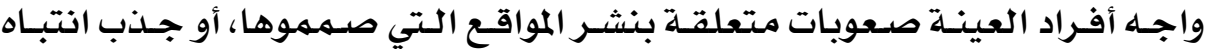

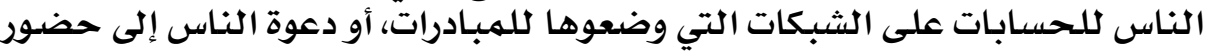

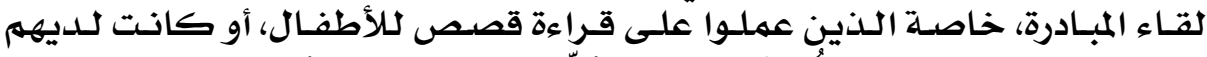

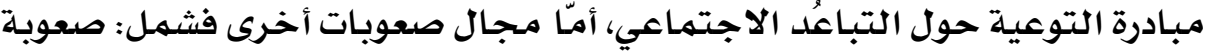

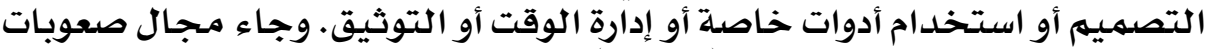

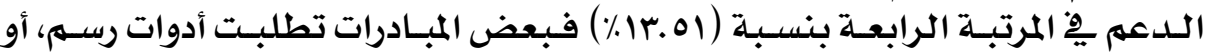

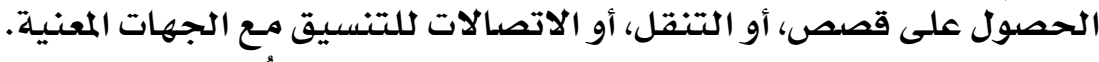

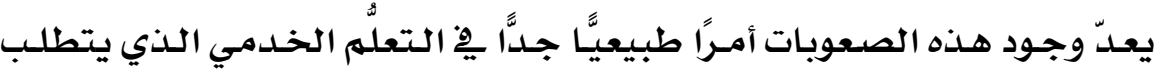

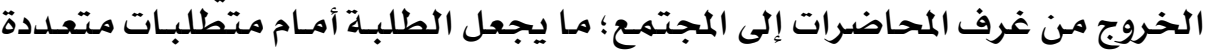

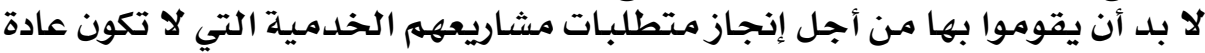

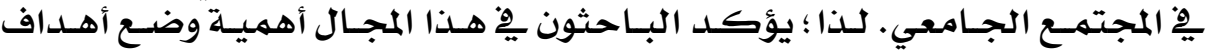

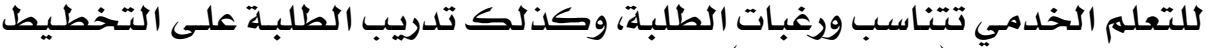

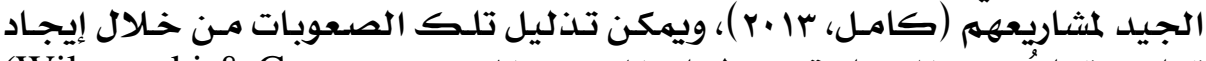

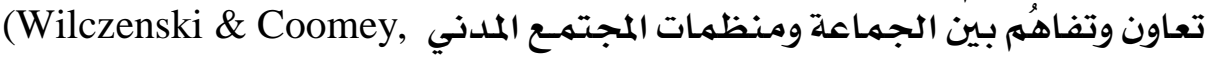

\section{$\bullet \wedge$}




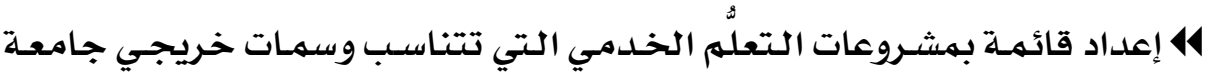

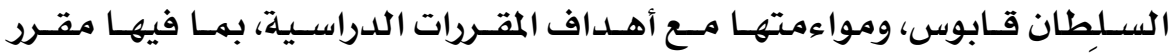

المواطنة العالميلة.

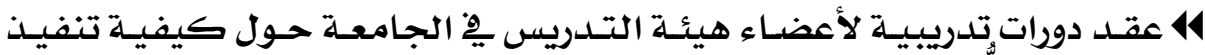
مدخل التعليم الخدمي.

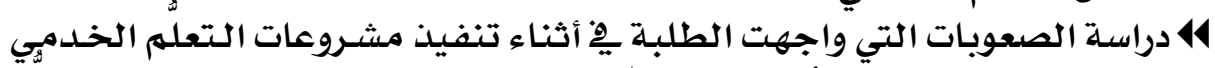

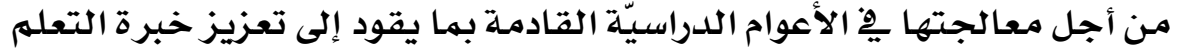

\section{الخدمي لدى الطلبـة. \\ • الدراسات الاقتزحة:}

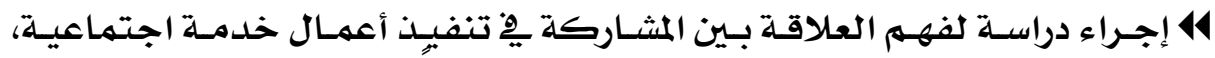

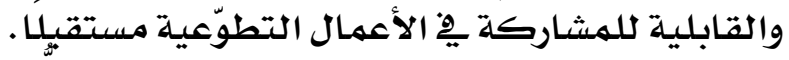

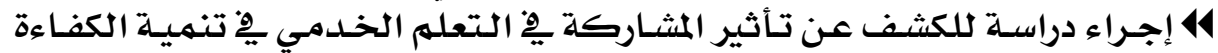
الذاتيـة لدى طلبـة مؤسسات دراته التعليهم العالي.

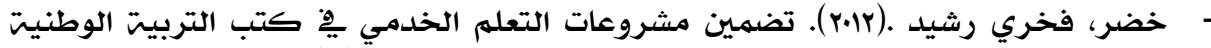

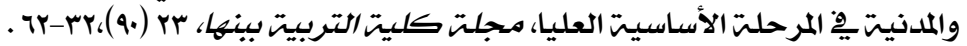

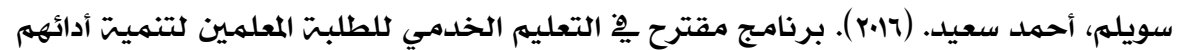

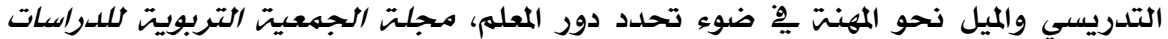

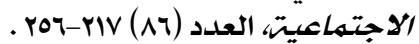

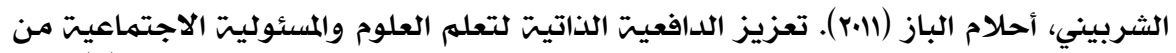

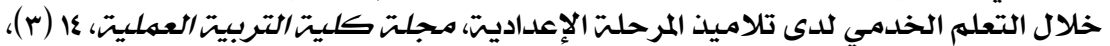

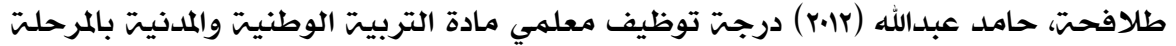

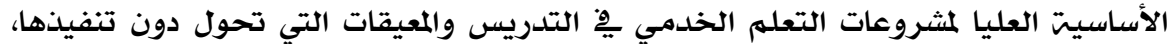

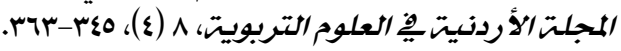

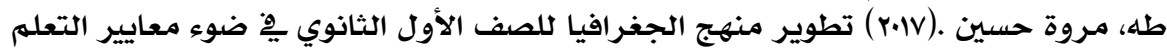

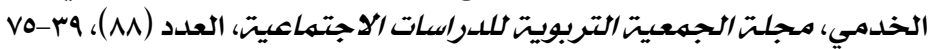

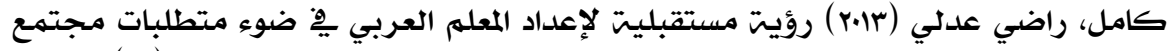

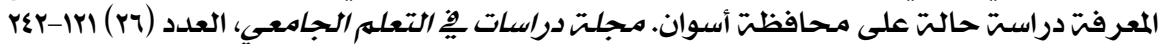

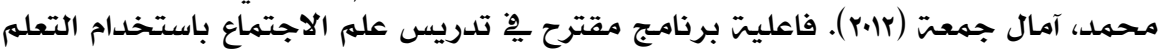

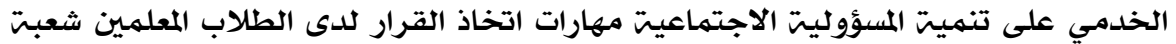

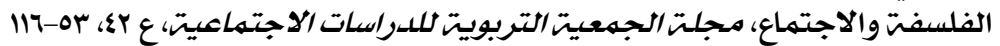

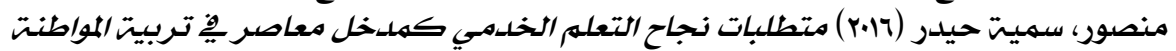

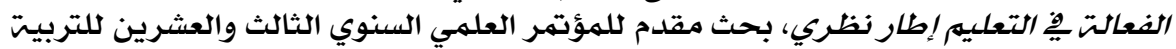

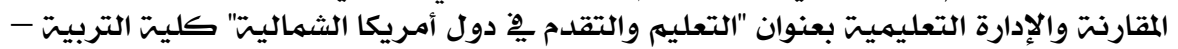

جامعت عين شمس

\section{$\bullet 9$}




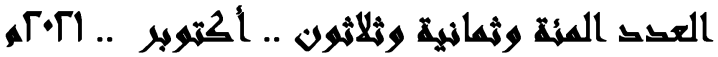

- Bernadowski, C., Perry, R., \& Greco, R. (2013). Improving preservice teachers' self-efficacy through service learning: lessons learned, International Journal of Instruction, 6 (2). 67-86

- Bollin G. (2007). Preparing teachers for Hispanic immigrant children: a service-learning approach, Journal of Latinos and Education, 6 (2), 177-189.

- Boru, N. (2017). The effects of service learning and volunteerism activities on university students in Turkey, Journal of Education and Training Studies, 5 (6), 146-166.

- Kang, W. (2014). Korean pre-service teachers' service learning and lifelong learning competency, $5^{\text {th }}$ World Conference on Education Sciences, WCES, Procedia,

- Power, A., Truong, S., Gray, T., Downey, G., Hall, T., and Jones, B. (2017). When outbound mobility programs and service learning align in pre-service teacher education, Asia Pacific Education Review, 18 (3) : 401-412

- Soykan, E., Gunduz, N., \& Tezer, M (2015) Perceptions of the teacher candidates towards community service learning, ProcediaSocial and Behavioral Sciences, 197, 2468-2477.

- Xu, R. (2010) Comparing the differences and commonalities between service-learning in the USA and social practice in China, Citizenship and Social Justice, 55 (3). 235-247 